\title{
Effect of operational parameters and Pd/In catalyst in the reduction of nitrate using copper electrode
}

Thiago Favarini Beltrame, Vanessa Coelho, Luciano Marder, Jane Zoppas Ferreira, Fernanda Albana Marchesini \& Andrea Moura Bernardes

To cite this article: Thiago Favarini Beltrame, Vanessa Coelho, Luciano Marder, Jane Zoppas Ferreira, Fernanda Albana Marchesini \& Andrea Moura Bernardes (2017): Effect of operational parameters and $\mathrm{Pd} / \mathrm{In}$ catalyst in the reduction of nitrate using copper electrode, Environmental Technology, DOI: $10.1080 / 09593330.2017 .1367422$

To link to this article: http://dx.doi.org/10.1080/09593330.2017.1367422

Accepted author version posted online: 18

Aug 2017.

Submit your article to this journal ¿

View related articles ¿

View Crossmark data ¿ 
Publisher: Taylor \& Francis \& Informa UK Limited, trading as Taylor \& Francis Group

Journal: Environmental Technology

DOI: $10.1080 / 09593330.2017 .1367422$

\title{
Effect of operational parameters and $\mathrm{Pd} / \mathrm{In}$ catalyst in the reduction of nitrate using copper electrode
}

\author{
Thiago Favarini Beltrame ${ }^{1}$, Vanessa Coelho ${ }^{1}$, Luciano Marder ${ }^{1}$, Jane Zoppas Ferreira ${ }^{1}$, Fernanda \\ Albana Marchesini ${ }^{2}$, Andrea Moura Bernardes ${ }^{*}$ \\ ${ }^{1}$ UFRGS (Universidade Federal do Rio Grande do Sul), Av. Bento Gonçalves, 9500, CEP 91509- \\ 900, Porto Alegre, RS, Brazil, \\ ${ }^{2}$ Instituto de Investigaciones en Catálisis y Petroquímica (FIQ-UNL, INCAPE-CONICET), Santiago \\ del Estero 2829, 3000 Santa Fe, Argentina \\ *Corresponding author. E-mail; amb@ufrgs.br
}

\section{Acknowledgments}

The authors would like to thank the Brazilian financial support from FINEP, FAPERGS, CNPq and CAPES, as well as the Argentinean funding from ANPCyT, UNL-FIQ and CCT Santa Fe - INCAPE - CONICET.

\begin{abstract}
Water with high concentration of nitrate may cause damage to health and to the environment. This study investigated how concentration, current density, flow, $\mathrm{pH}$, the use of $\mathrm{Pd} / \mathrm{In}$ catalyst and operating mode (constant current density and constant cell potential) have an influence in the electrochemical reduction of nitrate and in the formation of gaseous compounds using copper electrode. Experiments were performed in two-compartment electrolytic cells separated by a cationic membrane with nitrate model solutions prepared as a surrogate of concentrated brines from membrane desalination plants. The results show that the electroreduction process has potential for reduction of nitrate and that it is influenced by the operational conditions. The best conditions found for the treatment - with satisfactory reduction of nitrate, formation of gaseous compounds and
\end{abstract}


reproducibility - were at nitrate concentrations of 600 and $1000 \mathrm{mg} . \mathrm{L}^{-1}$, current density of $1.1 \mathrm{~mA} \cdot \mathrm{cm}^{-2}$ and without $\mathrm{pH}$ control, since in these conditions the production of gaseous compounds is higher than the production of nitrite. When $\mathrm{Pd} / \mathrm{In}$ catalyst was used, the nitrate reduction was $50 \%$ after 6 hours of experiment and the predominant product were gaseous compounds. When compared to the experiment without the catalyst, the arrangement with Pd/In was the most efficient one.

Keywords: Membrane concentrated brines; Nitrate reduction; Electroreduction; Copper electrode; $\mathrm{Pd} / \mathrm{In}$ catalyst

\section{Introduction}

The contamination by nitrate $\left(\mathrm{NO}_{3}{ }^{-}\right)$has become a problem to the environment and to human health due to its harmful effects [1]. The excess of nitrate in surface water is caused by fertilizers and particular effluents with nitrogen [2]. This compound, when consumed in potable water, can be converted into nitrites $\left(\mathrm{NO}_{2}^{-}\right)$in the human body, a fact that might cause health damage [3].

There are several methods of water denitrification [4] as the processes of biological or catalytic reduction and of degradation and separation, such as distillation, ion exchange, electrodialysis and reverse osmosis [2] [5-6]. The biological process of denitrification requires continuous monitoring to allow the growth of microorganisms [7] and this kind of treatment may generate sludge. In recent decades, the catalytic reduction, in which the nitrate ion is reduced to nitrogen by using hydrogen or other reducing agents, can be considered a promising process to the treatment of nitrate [8-9]. Among the catalysts for reduction of nitrate in water, there are bimetallic systems based on Cu modified by Pd and In [10-11].

Another way to treat contaminated water containing nitrate ions is through Membrane Separation Processes (MSP), for example electrodialysis (ED). This process involves a separation by selective ion membranes, in which there is ion transport from one solution to another [12-13]. It is generated a concentrated solution and a diluted one (treated). The concentrated solution, if not reused, consists of a new effluent that requires treatment. Menkouchi Sahli et al. [14] removed nitrate of underground brackish water by electrodialysis referring to the concentrated nitrate solution obtained during the treatment as the main disadvantage.

Electrochemical reduction is an alternative technology to the treatment for the removal of nitrates and nitrites from wastes [15-18]. The electrochemical reduction of nitrate is getting more attention due to its reasonable cost and the possibility of generating nitrogen as a final product of this 
process [19], which is beneficial to the environment. Several electrodes can be used in order to convert the nitrate to other nitrogen compounds; however, copper is a good promoter of the electroreduction reaction [19-20]. In comparison with the biological treatment, the electrochemical process for the treatment of wastewater has been considered as advantageous, because there is a minimum sludge generation and a smaller equipment with higher efficiency can be used [21-23]. Dash and Chaudhari [21] evaluated the electrochemical denitrification of a solution containing $100 \mathrm{mg} . \mathrm{L}^{-1}$ of nitrate and the results demonstrated a reduction of nitrate with $\mathrm{Al}, \mathrm{Fe}$ and $\mathrm{Ti}$ electrodes. According to Prasad et al. [24], the electrolytic method using copper electrode with current density of $0.89 \mathrm{~mA} . \mathrm{cm}^{-2}$ and setting the $\mathrm{pH}$ at 8 , during 6 hours, can potentially remove $70 \%$ of nitrate in an effluent with $190 \mathrm{mg} . \mathrm{L}^{-1}$ of nitrate.

The reduction of nitrate can generate several by-products [25]. In the overall reaction, nitrate is converted to nitrite, nitrogen $\left(\mathrm{N}_{2}\right)$ and other products (reactions 1 to 3 ). Nitrite acts as an intermediate product in the electrochemical nitrate reduction process, since its intermediate oxidation state allows it to be oxidized or reduced [26].

$\mathrm{NO}_{3}^{-}{ }_{(\mathrm{aq})}+\mathrm{H}_{2} \mathrm{O}_{(\mathrm{l})}+2 \mathrm{e}^{-} \rightarrow \mathrm{NO}_{2}^{-}{ }_{(\mathrm{aq})}+2 \mathrm{OH}_{(\mathrm{aq})}^{-}$

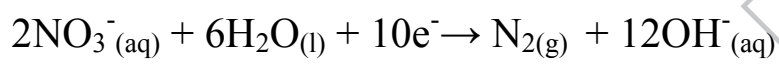

$2 \mathrm{NO}_{2}^{-}(\mathrm{aq})+4 \mathrm{H}_{2} \mathrm{O}_{(\mathrm{l})}+6 \mathrm{e}^{-} \rightarrow \mathrm{N}_{2(\mathrm{~g})}+8 \mathrm{OH}_{(\mathrm{aq})}^{-}$

Through the reduction of nitrate or nitrite, ammonium $\left(\mathrm{NH}_{4}{ }^{+}\right)$(reactions 4 and 5) [10] and others species may be formed [26-28] like, for example, $\mathrm{NO}_{2(\mathrm{~g})}, \mathrm{N}_{2} \mathrm{O}_{(\mathrm{g})}, \mathrm{NO}_{(\mathrm{g})}, \mathrm{N}_{2} \mathrm{O}_{5(\mathrm{~s})}$ and $\mathrm{N}_{2} \mathrm{O}_{3(\mathrm{~s})}$.

$\mathrm{NO}_{3(\mathrm{aq})}^{-}+4 \mathrm{H}_{2(\mathrm{~g})} \rightarrow \mathrm{H}_{2} \mathrm{O}_{(\mathrm{aq})}+\mathrm{NH}_{4}^{+}{ }_{(\mathrm{aq})}+2 \mathrm{OH}_{(\mathrm{aq})}^{-}$

$\mathrm{NO}_{2}^{-}{ }_{(\mathrm{aq})}+3 \mathrm{H}_{2(\mathrm{~g})} \rightarrow \mathrm{NH}_{4}^{+}{ }_{(\mathrm{aq})}+2 \mathrm{OH}^{-}{ }_{(\mathrm{aq})}$

The aim of this study was to investigate the electroreduction of nitrate solutions and to evaluate how parameters like the concentration, current density, flow, $\mathrm{pH}$ and use of $\mathrm{Pd} / \mathrm{In}$ catalyst can influence the reduction of nitrate aiming the formation of gaseous compounds. For this purpose it was used a model solution produced as a surrogate of an electrodialysis brine.

\section{Experimental section}




\subsection{Solutions}

Model solutions were prepared and treated by electroreduction. Different nitrate solutions were prepared with sodium nitrate $\left(\mathrm{NaNO}_{3}\right.$, distributed by Reagen) in distilled and deionized water. The model solutions were prepared with nitrate concentrations corresponding to those obtained in the concentrated brines from membrane desalination plants [29-31]. The concentration of the nitrate ion in the solutions was 200,600 and $1000 \mathrm{mg} . \mathrm{L}^{-1}$. Solution of sodium sulfate anhydrous $\left(\mathrm{Na}_{2} \mathrm{SO}_{4}\right.$, distributed by Labsynth) was also employed in the experiments to provide and maintain conductivity in the electrolytic cells. Table 1 shows a summary of solutions used in the experiments.

\subsection{Chemical characterization}

The nitrate, nitrite and ammonium/ammonia concentration were obtained through ion chromatography (DIONEX ICS 3000 Chromatograph with IonPac CS12A and AS22 columns for cations and anions, respectively). The reproducibility of the analytical method was evaluated through a sample containing $588 \mathrm{mg} . \mathrm{L}^{-1}$ of nitrate, with a confidence interval of $95 \%$ and a standard deviation of $\pm 3 \mathrm{mg} . \mathrm{L}^{-1}$. The nitrate removal efficiency was calculated using the equation (eq. 6 ).

$\mathrm{R}_{\text {Nitrate }}^{\text {Reduction }}(\%)=\left[\frac{\mathrm{C}_{0}-\mathrm{C}_{\mathrm{N}-\text { nitrate }}}{\mathrm{C}_{0}}\right] \times 100$

where $C_{0}$ is the initial concentration of nitrate. The calculations were performed by using $\left(C_{N}\right)$ Nbased concentrations.

The concentration values of gaseous compounds were obtained by mass balance, subtracting, from the initial nitrate concentration, the formation of nitrite and ammonium, and considering that the other formed species are gaseous compounds (eq. 7).

$\underset{\text { Compounds }}{\mathrm{C}_{\text {Gaseous }}}(\%)=\left[\left(\mathrm{C}_{\text {Nitrate }}\right)-\left(\left(\mathrm{C}_{\text {Nitrite }}\right)+\left(\mathrm{C}_{\text {Ammonium }}\right)\right)\right] \times 100$

Among other byproducts that can be formed in the experiments, there is the hydroxylamine $\left(\mathrm{NH}_{2} \mathrm{OH}\right)$. Hydroxylamine is an alkaline compound containing the hydroxylammonium $\left(\left[\mathrm{NH}_{3} \mathrm{OH}\right]^{+}\right)$ ion. In acid or alkaline medium, there is the dissociation of the compound according to reaction 8 and 9, respectively. In acid solutions, ammonium ion can be formed (eq. 8), while in alkaline 
solutions there is the formation of ammonia gas (eq. 9) [32], meaning that this product will be also considered by its byproducts analysis.

$4\left[\mathrm{NH}_{2} \mathrm{OH} . \mathrm{H}\right]^{+} \rightarrow \mathrm{N}_{2} \mathrm{O}+2 \mathrm{NH}_{4}^{+}+2 \mathrm{H}^{+}+3 \mathrm{H}_{2} \mathrm{O}$

$3 \mathrm{NH}_{2} \mathrm{OH} \rightarrow \mathrm{N}_{2}+\mathrm{NH}_{3}+3 \mathrm{H}_{2} \mathrm{O}$

\subsection{Catalyst preparation}

Pd-In was prepared supporting the metal precursors on alumina (Ketjen CK300, surface area: $198 \mathrm{~m}^{2} / \mathrm{g}$, pore volume: $0.5 \mathrm{~mL} \cdot \mathrm{g}^{-1}$ ) by the dry co-impregnation method also described elsewhere [33], using solutions containing $\mathrm{In}_{2} \mathrm{O}_{3}$ and $\mathrm{PdCl}_{2}$ dissolved in $\mathrm{HCl} 0.1 \mathrm{M}$. Metal loads of $1.25 \%$ wt In and 5.00\%wt Pd were obtained. All samples were calcined in air, at $500{ }^{\circ} \mathrm{C}$, for $4 \mathrm{~h}$. Prior the catalytic evaluation reaction, catalysts were reduced for $1 \mathrm{~h}$ at $40^{\circ} \mathrm{C}$ in Hydrazine solution $0.04 \% \mathrm{~V} / \mathrm{V}$.

\subsection{Design cells $A$ and $B$}

Two electrolytic cells were used at this study. Cell A was employed to evaluate all operational parameters of nitrate reduction, while cell B was used in order to test the influence of using $\mathrm{Pd} / \mathrm{In}$ catalyst in the reduction of nitrate. Each experiment was performed at least in triplicate. Figure 1 presents the methodology used in this work.

\subsubsection{Design of cell $A$}

The electrolytic cell A (Figure 2) was a two-compartment cell separated by a cationic membrane HDX 100 (supplied by Hidrodex). In the cathode compartment $\mathrm{NaNO}_{3}$ was added and in the anode one $\mathrm{Na}_{2} \mathrm{SO}_{4}$ was fed. In each compartment $500 \mathrm{~mL}$ of solution was used. The cationic membrane prevents the nitrate, which was already reduced in the cathode, to be oxidized in the anode. Both compartments are connected to centrifugal pumps that provide a continuous flow of solutions into the system.

According to Dos Reis and Mendonça [34], the pH increase shift the ammonium/ammonia chemical equilibrium toward unionized ammonia, so a gas scrubber was used with $\mathrm{HCl}(0.05 \mathrm{M})$ to collect the gas that could escape during the experiments. The chemical reaction (eq. 10) that occurs in the acid solution converts the ammonia, which might be formed in the reduction process, into 
ammonium. The analysis of this acid solution, that could contain the ammonium ion, was also performed by ion chromatography.

$\mathrm{HCl}_{(\mathrm{aq})}+\mathrm{NH}_{3(\mathrm{~g})} \rightarrow \mathrm{NH}_{4}^{+}{ }_{(\mathrm{aq})}+\mathrm{Cl}_{(\mathrm{aq})}^{-}$

The usual cell flow was $1900 \mathrm{~mL} \cdot \mathrm{min}^{-1}$ in the cathode compartment and $2100 \mathrm{~mL} \cdot \mathrm{min}^{-1}$ in the anode compartment. The difference of flows in the compartments was due to differences in the centrifugal pumps. To all experiments, the working electrode in the cathode compartment was copper and in the anode one was $\mathrm{Ti} / 70 \mathrm{TiO}_{2} 30 \mathrm{RuO}_{2}$.

During the experiments, the $\mathrm{pH}$ of the solutions in the cathode and anode compartments was monitored and the measurements were performed by a PHTEK $\mathrm{pH}$ meter (model PH-3B). The solutions conductivities were also monitored and the values were obtained from a RS232 conductivity meter (model 8306).

\subsubsection{Design of cell B}

A smaller cell model was used to test the effect of $\mathrm{Pd} / \mathrm{In}$ catalyst. The cell has two compartments (Figure 3), also separated by a cationic membrane HDX 100, and in the cathode and in the anode compartments $180 \mathrm{~mL}$ of $\mathrm{NaNO}_{3}$ and $\mathrm{Na}_{2} \mathrm{SO}_{4}$ were respectively added. The agitation of the solutions was carried out by magnetic stirring. The same electrodes that were already mentioned (cell A) were used.

\subsection{Polarization curves}

Current-voltage curves (CVC) were constructed to determine the limiting current of the cationic membrane and to obtain the value of current density that can provide the reduction of nitrate without causing polarization phenomenon on the membrane. This phenomenon could affect the system because it occurs when the applied current exceeds a limiting value, causing a reduction of ions to zero in one side of the membrane, while there is an accumulation of ions at other side of the membrane. Then, the polarization phenomenon may cause an increase in electrical resistance, increasing the energy consumption [35]. The CVC curves were obtained by applying an electric current that was gradually increased for 120 seconds, with an interval of 180 seconds without current application. Platinum wires were placed on each side of the cation-exchange membrane to measure 
the membrane potential difference [36]. During the CVC construction, the cathode and the cell potentials were also measured. The cathode potential was obtained using Luggin's capillary with $\mathrm{Ag} / \mathrm{AgCl}$ as reference electrode. This measurement allows the evaluation of the potential range to nitrate reduction. The system used to obtain the CVC curves is presented in a scheme in Figure 4. These tests were performed at least in duplicate.

\subsection{Electroreduction}

The electroreduction experiments were conducted in cell A and B.

\subsubsection{Cell A electroreduction}

In this step, the influence of concentration, current density, $\mathrm{pH}$ and flow were studied. All experiments were performed for a period of 12 hours and each 2 hours samples were collected to evaluation by ion chromatography. The cationic membrane area was $16 \mathrm{~cm}^{2}$, the copper electrode area was $15 \mathrm{~cm}^{2}$ and the geometric area of the anode electrode $\left(\mathrm{Ti} / 70 \mathrm{TiO}_{2} 30 \mathrm{RuO}_{2}\right)$ was $16 \mathrm{~cm}^{2}$. The $\mathrm{pH}$ influence study was accomplished controlling the $\mathrm{pH}(4.0-4.5$ and $7.0-7.5)$ and without control. The $\mathrm{pH}$ control was made in the cathode compartment because in this compartment occurs the reactions of nitrate reduction. The $\mathrm{pH}$ adjustment was done by adding constantly, with a burette, $\mathrm{H}_{2} \mathrm{SO}_{4}(0.5 \mathrm{M})$. The $\mathrm{pH}$ value was obtained using the PHTEK $\mathrm{pH}$ meter (model PH-3B).

The flow parameter was evaluated by reducing the normal centrifugal pumps flow values from $1900 \mathrm{~mL} \cdot \mathrm{min}^{-1}$ to $460 \mathrm{~mL} \cdot \mathrm{min}^{-1}$ in the cathode compartment and from $2100 \mathrm{~mL} \cdot \mathrm{min}^{-1}$ to $990 \mathrm{~mL} \cdot \mathrm{min}^{-1}$ in the anode compartment.

Experiments were conducted with constant cell current or constant cell potential. The mode with constant cell current was performed by fixing the current density in 1.1 or $2.1 \mathrm{~mA} . \mathrm{cm}^{-2}$ and the constant cell potential was carried out by fixing the cell potential in $5 \mathrm{~V}$ or $7 \mathrm{~V}$. Nitrate solutions concentration of 200,600 and $1000 \mathrm{mg} . \mathrm{L}^{-1}$ were evaluated.

\subsubsection{Cell B electroreduction}

In this step, the influence of using a Pd/In catalyst was evaluated. The $\mathrm{Pd} / \mathrm{In}$ catalyst was placed in the electroreduction cell by an inert support in the cathode compartment, the closest possible to the copper electrode, but without touching the electrode to avoid an electrical contact (Figure 3). The hydrogen produced in the surface of the copper electrode will diffuse to the surface 
of the $\mathrm{Pd} / \mathrm{In}$ catalyst, where the $\mathrm{Pd}$ is able to dissociate the hydrogen in two adsorbed atoms. Then, the nitrates will be reduced to nitrite, being the $\mathrm{NO}_{2}{ }^{-}$formed reduced to ammonium or nitrogen, depending on the environmental conditions. The mass of $\mathrm{Pd} / \mathrm{In}$ used was of $0.29 \pm 0.02 \mathrm{~g}$ to the treatment of $180 \mathrm{~mL}$ of nitrate solution. These experiments were performed for 6 hours and the initial and final samples were collected to evaluation. The cationic membrane area was $16 \mathrm{~cm}^{2}$, the copper electrode area was $15 \mathrm{~cm}^{2}$ and the geometric area of anode electrode $\left(\mathrm{Ti} / 70 \mathrm{TiO}_{2} 30 \mathrm{RuO}_{2}\right)$ was $16 \mathrm{~cm}^{2}$. Briefly, experiments were executed with and without $\mathrm{Pd} / \mathrm{In}$ catalyst using $\mathrm{pH}$ values without control or by controlling the $\mathrm{pH}$ between 6 and 6.5 . The $\mathrm{pH}$ was controlled by adding constantly $\mathrm{H}_{2} \mathrm{SO}_{4}(0.5 \mathrm{M})$, in the cathode compartment, using a burette.

\section{Results and discussion}

\subsection{Current-voltage curves $(\mathrm{CVC})$}

Figure 5 shows the current-voltage curves obtained for the cationic membrane in contact with nitrate solutions. Classical three regions were obtained (highlighted in Figure 5 to the concentration of $\left.1000 \mathrm{mg} . \mathrm{L}^{-1}\right)$. In region I there is a linear relationship between the current density and voltage of the membrane due to the ohmic region. In the second region, the current varies slightly with the voltage corresponding to the limiting current density. In the region III a further increase of current occurs, and it leads to increased current density with the applied voltage [37]. For the electroreduction experiments (constant current density mode), 75\% of the limiting current density value obtained to the concentration of $600 \mathrm{mg} . \mathrm{L}^{-1}$ was used. The current density applied was $1.1 \mathrm{~mA} \cdot \mathrm{cm}^{-2}$. The use of current densities smaller than the limiting one avoids the concentration polarization phenomenon in the membrane [36][38]. Although a limiting current density of $0.5 \mathrm{~mA} . \mathrm{cm}^{-2}$ was obtained for the solution concentration of $200 \mathrm{mg} . \mathrm{L}^{-1}$, a $1.1 \mathrm{~mA} . \mathrm{cm}^{-2}$ current density was also applied for comparison with the other concentration. In order to verify the effect of current density on conversion to gaseous compounds, trials with a current density of $2.1 \mathrm{~mA} . \mathrm{cm}^{-2}$ were also carried out using the concentration of $600 \mathrm{mg} . \mathrm{L}^{-1}$.

During the CVC construction, cathode and cell potential were also determined. It was observed in the curve of Figure 6 that from a cell potential value of $5 \mathrm{~V}$, there is a separation between the cell and the cathode potentials. This indicates that, beginning at $5 \mathrm{~V}$, chemical reactions are occurring in the solution. Other assays using $7 \mathrm{~V}$ as cell potential were accomplished because, by using a current density of $1.1 \mathrm{~mA} . \mathrm{cm}^{-2}$ with a concentration of $600 \mathrm{mg} \cdot \mathrm{L}^{-1}$ of $\mathrm{NO}_{3}^{-}, 7 \mathrm{~V}$ was obtained 
as initial cell potential. According to the Pourbaix Diagram [39], the obtained values in the cathode potential $\left(0.9 \mathrm{~V}_{\mathrm{H}}\right.$ and $\left.1.2 \mathrm{~V}_{\mathrm{H}}\right)$ for cell potential of 5 and $7 \mathrm{~V}$, respectively, indicate the possibility of nitrate ion reduction to nitrite ion and to nitrogen gas.

\subsection{Electroreduction experiments with copper electrodes (cell A)}

\subsection{1. $\mathrm{pH}$, conductivity and cell potential behavior}

The $\mathrm{pH}$ behavior, when not controlled, seems to be similar for all working solution concentrations. Figure 7 shows the $\mathrm{pH}$ variation for the $600 \mathrm{mg} \cdot \mathrm{L}^{-1}$ nitrate solution. In the cathode compartment the value increases and at the end of 12 hours the $\mathrm{pH}$ was 11.5 . In the study by Li et al. [18] the $\mathrm{pH}$ value of the treated solution increased from 7.0 to 11.3 during 3 hours of electrolysis in a solution with $100 \mathrm{mg} . \mathrm{L}^{-1}$ of nitrate- $\mathrm{N}$ using Fe electrode. In the anode compartment, the $\mathrm{pH}$ value decreases, staying in the range of $2.4-2.5$, at the concentration of $600 \mathrm{mg}$. $\mathrm{L}^{-1}$ [18].

In the cathode compartment, it occurs the reaction of $\mathrm{H}_{2}$ and $\mathrm{OH}^{-}$formation, while in the anodic compartment, $\mathrm{O}_{2}$ and $\mathrm{H}^{+}$are formed, as shown in equations (11), (12), (13) and (14) [23].

Cathode:

$2 \mathrm{H}^{+}(\mathrm{aq})+2 \mathrm{e}^{-} \rightarrow \mathrm{H}_{2(\mathrm{~g})}$

$2 \mathrm{H}_{2} \mathrm{O}_{(\mathrm{l})}+2 \mathrm{e}^{-} \rightarrow \mathrm{H}_{2(\mathrm{~g})}+2 \mathrm{OH}^{-}$(aq)

Anode:

$2 \mathrm{H}_{2} \mathrm{O}_{(\mathrm{l})} \rightarrow 4 \mathrm{H}_{(\mathrm{aq})}^{+}+\mathrm{O}_{2}(\mathrm{~g})+4 \mathrm{e}^{-}$

$4 \mathrm{OH}_{(\text {aq })}^{-} \longrightarrow 2 \mathrm{H}_{2} \mathrm{O}_{(\mathrm{l})}+\mathrm{O}_{2(\mathrm{~g})}+4 \mathrm{e}^{-}$

The $\mathrm{pH}$ (Figure 7) and the conductivity (Table 2) changes occur due to the reactions that happened at the electrodes generating, $\mathrm{H}^{+}$and $\mathrm{OH}^{-}$. Still, hydroxide is also produced from nitrate and nitrite reduction contributing also to the $\mathrm{pH}$ increase when the electrochemical reaction progressed (eq. 1, 2 and 3) [15], [40-41].

The increase of the conductivity (Table 2) causes a reduction in cell resistance and this provides a reduction of cell potential as show in Table 2 . The cell potential is an indicative of the 
behavior of the system resistance. In this case, as the cell potential reduces along the time, the resistance of the electroreduction cell decreases, causing a reduction the energy consumption.

\subsubsection{Effect of concentration}

The effect of concentration was determined considering the $\mathrm{NO}_{3}^{-}$and $\mathrm{NO}_{2}^{-}$analyzed concentration and the N-Gaseous compounds calculated concentration. The calculation was done considering that according to the Pourbaix Diagram the $\mathrm{N}_{2} \mathrm{O}$ formation is not probable.

For the concentration of $600 \mathrm{mg} . \mathrm{L}^{-1}$ (Figure 8, A), until 8 hours, a highest concentration of $\mathrm{N}-$ Nitrite instead of N-Gaseous compounds was observed. After this time, the concentration of gaseous compounds begins to increase being similar, however, the obtained values of N-Nitrite and $\mathrm{N}-$ Gaseous compounds. The electrode potential at $600 \mathrm{mg} \cdot \mathrm{L}^{-1}$ concentration was monitored and the initial and final values were $0.7 \mathrm{~V}_{\mathrm{H}}$ and $0.9 \mathrm{~V}_{\mathrm{H}}$, respectively. With this electrode potentials and $\mathrm{pH}$ 11.5, utilizing the Pourbaix Diagram [39], the principal gaseous produet that can be formed is the $\mathrm{N}_{2}$.

For the concentration of $1000 \mathrm{mg} . \mathrm{L}^{-1}$ (Figure 8, B), the behavior of the products concentration formed were similar to those detected for the concentration of $600 \mathrm{mg}$. $\mathrm{L}^{-1}$. After 6 hours of reaction, the concentration of N-Gaseous compounds was higher than nitrite concentration; however, the values obtained were close.

At the concentration of $200 \mathrm{mg}^{-L^{-1}}$ (Figure 8, C), it was observed that there were more N-Gaseous compounds formed than N-Nitrite. However, after 6 hours of experiment (not shown), the reactions became chaotic and non-replicable, probably due to the applied current density of $1.1 \mathrm{~mA} . \mathrm{cm}^{-2}$, which was above the required current density (Figure 5) for this concentration. In fact, in this current density, hydrogen and oxygen formation could be responsible for the non-replicable experiments, because by increasing current intensity the production of $\mathrm{OH}^{-}$and $\mathrm{H}^{+}$is favored.

It was possible to identify nitrite as an intermediate product in the three concentrations. Sinha [42] studied that the applied cell voltage is a critical parameter in electrolysis. According to the applied voltage, different products can be formed [43]. The applied current is possibly not ideal to reduce the ion nitrate into gaseous nitrogen, but to reduce ion nitrate into nitrite. The water splitting could compete with the nitrate reduction [42] and this can be an obstacle to the $\mathrm{NO}_{3}{ }^{-}$reduction.

\subsubsection{Effect of current density}

In order to verify the influence of the current density in the reduction of nitrate, a study with nitrate solution concentration of $600 \mathrm{mg} . \mathrm{L}^{-1}$ was carried out with $2.1 \mathrm{~mA} . \mathrm{cm}^{-2}$, which practically 
corresponds to the double of the current density applied in the experiments of $1.1 \mathrm{~mA} . \mathrm{cm}^{-2}$. The $\mathrm{pH}$ showed the same behavior verified in the previous experiments and the conductivity in the cathode compartment was $2780 \mu \mathrm{S} . \mathrm{cm}^{-1}$, while in the anode compartment the conductivity was $3320 \mu \mathrm{S} . \mathrm{cm}^{-1}$, at the end of 12 hours.

As observed previously with the solution of $200 \mathrm{mg} \cdot \mathrm{L}^{-1}$, a high standard deviation was obtained (Figure 9). The high standard deviation can be also associated with the fact that the applied current density was above the one required for this concentration. Nevertheless, the N-Nitrate reduction (44\%) was higher with $2.1 \mathrm{~mA} \cdot \mathrm{cm}^{-2}$ than with $1.1 \mathrm{~mA} \cdot \mathrm{cm}^{-2}(35 \%)$ what could be associated to the obtained cell potential during the experiments with these current densities. Li et al. [18] and Kim et al. [15] obtained the same nitrate reduction behavior using undivided and divided cell, and different electrodes in cathode compartment.

\subsubsection{Effect of flow}

With the reduction of the flow (Figure 10), at the end of 12 hours and initial nitrate concentration of $600 \mathrm{mg} \cdot \mathrm{L}^{-1}$, there was less N-Nitrate concentration $\left(79 \pm 3 \mathrm{mg} . \mathrm{L}^{-1}\right)$ if compared to the previous results obtained to higher flow (Figure 8, A). However, during the 12 hours of experiment, there was more N-Nitrite $\left(35 \pm 5 \mathrm{mg} . \mathrm{L}^{-1}\right)$ than N-Gaseous compounds.

It was possible to verify that the reduction of nitrate was higher than in normal flow. Szpyrkowicz et al. [44] studied the removal of nitrate from water by electrochemical reduction in different reactor configurations varying the flow during the experiments and they observed that stirring the solution in the cathode had a negative effect on the nitrates reduction, possibly due the transfer of oxygen from the gas phase. This could be the result of a reaction that competes with the nitrate reactions.

\subsubsection{Effect of $p H$}

The influence of $\mathrm{pH}$ was analyzed on the reduction of nitrate and formation of N-Gaseous compounds at the concentration of $600 \mathrm{mg} \cdot \mathrm{L}^{-1}$. The results obtained with $\mathrm{pH}$ control $(4.0-4.5$ and 7.0 - 7.5) indicated a small concentration of gaseous compounds, being the nitrate reduction equal to or greater than the one obtained in experiments after 12 hours, with a current density of $1.1 \mathrm{~mA} . \mathrm{cm}^{-2}$ and a gradual increase in $\mathrm{pH}$ (Figure 11). The nitrite concentration was higher when the $\mathrm{pH}$ of the cathode compartment was controlled with $\mathrm{H}_{2} \mathrm{SO}_{4}$, not favoring the formation of $\mathrm{N}$-Gaseous compounds. 
Prasad et al. [24] showed that the nitrate removal is similar by $\mathrm{pH} 7.0$ and 8.0. The author tested the influence at $\mathrm{pH} 2.0,4.0,6.0,8.0$ and 10.0, being the maximum nitrate reduction at $\mathrm{pH}$ 2.0. At $\mathrm{pH} 4.0$ the nitrate removal was similar to the one obtained at $\mathrm{pH}$ 6.0. Dortsiou et al. [45] observed that varying the $\mathrm{pH}$ between $0-4.0$, the nitrate reduction rate is proportional to $\mathrm{H}^{+}$ions concentration in the initial solution, what can be explained by the general theory of the electrochemical reduction of the anions of the second group with type $\mathrm{XO}_{3}{ }^{-}$, for example nitrate. In this $\mathrm{pH}$ region, the proton donor is the cation $\mathrm{H}^{+}$, so consequently, it is expected that the nitrate reduction rate should be proportional to the $\mathrm{H}^{+}$concentration, while in a $\mathrm{pH}>4$, the reduction rate does not depend on the $\mathrm{pH}$ once the donor is the water molecule.

\subsubsection{Effect of cell potential}

For the concentration of $600 \mathrm{mg} . \mathrm{L}^{-1}$, tests were carried out by setting the cell potential in $5 \mathrm{~V}$ and $7 \mathrm{~V}$. The value of $7 \mathrm{~V}$ and $5 \mathrm{~V}$ corresponds to the initial and final value, respectively, of the cell potential when the current of $1.1 \mathrm{~mA} \cdot \mathrm{cm}^{-2}$ was applied. During the experiments with the cell potential fixed at $7 \mathrm{~V}$, the applied current density increases over time (Table 4), reaching, after 12 hours, $3.87 \pm 0.12 \mathrm{~mA} . \mathrm{cm}^{-2}$. With $5 \mathrm{~V}$, the final value of the current density was $1.61 \pm 0.36 \mathrm{~mA} . \mathrm{cm}^{-2}$.

At $7 \mathrm{~V}$ there was a higher nitrate reduction than the one obtained on the experiments conducted with constant current density $\left(1.1 \mathrm{~mA} . \mathrm{cm}^{-2}\right)$, but the constant cell potential mode favored the intermediary ion formation. The nitrite formation was favored probably due to the increase of the current density (Table 4). Bosko et al, [26] obtained a nitrate reduction of around 40\% with a potential fixed at $7 \mathrm{~V}$ and nitrate solution concentration of $549.6 \mathrm{mg} . \mathrm{L}^{-1}$ and the main product obtained was nitrite, during 24 hours of experiment using a copper electrode. In the experiments where the potential was fixed at $5 \mathrm{~V}$ the final $\mathrm{N}-\mathrm{Nitrate}$ value was $105 \pm 3 \mathrm{mg} . \mathrm{L}^{-1}$ and N-Nitrite was the main ion produced (Table 3 ).

Referring to $\mathrm{pH}$ and conductivity values, when the potential was set in $7 \mathrm{~V}$, the $\mathrm{pH}$ presented the same behavior as previously mentioned (Figure 7) and the conductivity increases, being $2785 \mu \mathrm{S} . \mathrm{cm}^{-1}$ in the cathode compartment and $4460 \mu \mathrm{S} . \mathrm{cm}^{-1}$ in the anode compartment. In the experiments with $5 \mathrm{~V}$, the conductivity in the cathode compartment reached a maximum of $2475 \mu{\mathrm{S} . \mathrm{cm}^{-1}}^{-1}$, while the anode reached $4010 \mu{\mathrm{S} . \mathrm{cm}^{-1}}^{-}$. The values of conductivity in constant cell potential mode were higher than the ones achieved in constant current density mode due to the increase of current values during the experiments.

Mook et al. [23] highlight that operational parameters, such as electrode material, applied current, $\mathrm{pH}$ and the initial nitrate concentration, have an influence on the electrochemical 
denitrification. Ammonium and ammonia were not detected in the all experiments carried out in cell A and this could be associated to the hydrodynamic of this electroreduction cell and the values of current density used. The current density could be non-sufficient to provide the reduction of nitrate, producing $\mathrm{NH}_{3}$ and $\mathrm{NH}_{4}{ }^{+}$, but favorable to the reduction to nitrite. Couto et al. [25] studied the enhancement of nitrate electroreduction using BDD anode and metal modified carbon fiber cathode using $25 \mathrm{~mA} \cdot \mathrm{cm}^{-2}$ and $50 \mathrm{~mA} \cdot \mathrm{cm}^{-2}$ of current density. The results showed that with the highest current density, in undivided cell and using different electrodes, there is higher ammonium generation.

\subsection{Electrochemical experiments with Pd/In copper electrode (cell B)}

At first, an attempt was made in order to replicate the procedures of the first experiments the ones carried out in the electrolytic cell A. In order to achieve that, trials in the cell B were performed without the catalyst, and afterwards $\mathrm{Pd} / \mathrm{In}$ were placed in it, without the $\mathrm{pH}$ control of the cathode compartment. The results with the catalyst showed that the $\mathrm{pH}$ of the cathode compartment was next to 11.5, while the anode one was around 2.2, at the end of 6 hours of the experiment and these results were similar without the catalyst. The conductivity of the cathode and of the anode compartments increased over time with or without catalyst. Regarding the removal of nitrate, with and without the catalyst, a reduction of N-Nitrate and the generation of N-Gaseous compounds were similar in proportion (Figure 12). It can be also observed that, differently of what occurred in cell A, ammonium was detected at the end of the experiment in cell B without the catalyst. Probably it represents dissolved ammonia, since the final solution $\mathrm{pH}$ was close to 11.5. This result shows that the cell configuration and the hydrodynamic conditions possibly affect the nitrate reduction and the formed products.

Chen et al. [46] studied the appropriate conditions for maximizing catalytic reduction efficiency of nitrate into nitrogen gas in groundwater. The research shows that an $\mathrm{pH}$ increase resulted in a decrease in the initial activity, because when the ion nitrate was reduced to nitrogen gas, there is hydroxide formation and $\mathrm{OH}^{-}$could be accumulated, causing the restrained of nitrate reductions reactions. Therefore, low $\mathrm{pH}$ is better to catalytic activity, but a low $\mathrm{pH}$ level do not improve the selectivity to $\mathrm{N}_{2}$. Yang et al. [47] show that in nitrate hydrogenation on $\mathrm{Pd}-\mathrm{Cu} / \mathrm{TiO}{ }_{2}$ catalyst at $\mathrm{pH} 12.0$ there is a high selectivity to nitrite, however, in acid $\mathrm{pH}$ the nitrite is reduced to nitrogen selectively. This hydrogenation occurs because the hydrogen is active on palladium sites and reduces on these sites. 
Berndt et al. [48] adjusted the $\mathrm{pH}$ of their experiments in which palladium was used to 6.0 with $\mathrm{H}_{2} \mathrm{SO}_{4}$ or $\mathrm{HCl}$. Then, in order to control the $\mathrm{pH}$ of the cell $\mathrm{B}$, it was set between 6.0-6.5. Figure 13 shows the results with $\mathrm{pH}$ 6.0-6.5 with and without the $\mathrm{Pd} / \mathrm{In}$ catalyst. The results without the catalyst indicated a small reduction, and it is possible to notice that at the end of the experiment, there was $91 \pm 8 \mathrm{mg} . \mathrm{L}^{-1}$ of N-Nitrate in solution and only $19 \pm 8 \mathrm{mg} . \mathrm{L}^{-1}$ of N-Gaseous compounds. With the catalyst, there was a reduction of $50 \pm 1 \%$, and $68 \pm 1 \mathrm{mg} . \mathrm{L}^{-1}$ of N-Nitrate was present at the end of the assay. In this case, the formation of gaseous compounds was predominant. The use of catalyst provided a low formation of nitrite, suggesting the occurrence of nitrite hydrogenation, according to eq. (15) [49-50]:

$2 \mathrm{NO}_{2(\mathrm{aq})}^{-}+3 \mathrm{H}_{2(\mathrm{~g})}+2 \mathrm{H}^{+} \stackrel{\text { Pd }}{\rightarrow} \mathrm{N}_{2(\mathrm{~g})}+4 \mathrm{H}_{2} \mathrm{O}_{(\mathrm{aq})}$

Zhao et al. [51] have carried out kinetic tests and indicated that $0.4 \% \mathrm{Pd}-4 \% \mathrm{Cu} / \mathrm{Al}$ at $\mathrm{pH} 4.0$ resulted in the greatest selectivity for nitrogen, reaching a selectivity of $34.1 \%$ to the gas $\mathrm{N}_{2}$.

The low conversion values for nitrite and consequent formation of gaseous and ammonium compounds can be explained by the selectivity of $\mathrm{Pd}$ in reducing nitrate to these compounds. Zhang et al. [52] studied the electrocatalytic reduction of nitrate with $\mathrm{Pd}-\mathrm{Cu} / \mathrm{VAl}_{2} \mathrm{O}_{3}$ in the cathode compartment and a high nitrate reduction was obtained with a current density of 10 and $15 \mathrm{~mA} . \mathrm{cm}^{-2}$, with a low selectivity for the nitrite ion.

The cationic membrane avoids the transport of ion nitrate and nitrite to anodic compartment; however, the ammonium ion can be transported (Figure 14). Therefore, in this compartment, to all experiments- cell $\mathrm{A}$ and $\mathrm{B}$, analyses by ion chromatography were accomplished to detect the presence of ammonium. The results showed that there was no $\mathrm{NH}_{4}{ }^{+}$in the anodic compartment.

\section{Conclusion}

Nitrate contaminated water is an usual source of drinking water. Water treatment Plants (WTP) must deal with this problem and the use of Membrane Separation processes (MSP) is increasing to handle with this contamination. Nevertheless, MSP produce not only water of a very high quality, but also a concentrated solution and the treatment of these brines is a challenge for WTP. This work shows that the electrolytic reduction has the potential to be used as a way of treating concentrated nitrate effluents resulting from, for example, the water treatment by electrodialysis. The experiments conducted here allowed us to identify and to relate important 
parameters that influence the process of reduction of nitrate by using copper electrode, as the nitrate concentration, $\mathrm{pH}$, flow, current density, the operation mode (constant current density and constant cell potential) and the use of $\mathrm{Pd} / \mathrm{In}$ catalyst. In fact, the research results documented that the use of membrane electrolysis with copper electrode associated to $\mathrm{Pd} / \mathrm{In}$ catalyst is a promising process to the reduction of nitrate with favorable conditions to gaseous compounds production instead of nitrites generation.

\section{References}

[1] Primo O, Rivero MJ, Urtiaga AM, Ortiz I. Nitrate removal from electro-oxidized landfill leachate by ion exchange. J Hazard Mater. 2009;164:389-393.

[2] Barrabés N, Sá J. Catalytic nitrate removal from water, past, present and future perspectives. Appl Catal B Environ. 2011;104:1-5.

[3] Dodouche I, Barbosa DP, Rangel M. do C, Epron F, Palladium-tin catalysts on conducting polymers for nitrate removal, Appl Catal B Environ. 2009;93:50-55.

[4] Mahmoud MHH, Abdel-Aal EA, Abdel-hamed RM, Kandil AT. Denitration of coke plant wastewater using a Bench-Scale Electrodialysis Unit Via Statistical Design. Int J Electrochem. Sci. 2015;10:1478-93.

[5] Schoeman JJ, Steyn A. Nitrate removal with reverse osmosis in a rural area in South Africa. Desalination. 2003;155:15-26.

[6] Haugen KS, Semmens MJ, Novak PJ. A novel in situ technology for the treatment of nitrate contaminated groundwater. Water Research. 2002;36:3497-3506.

[7] Matějŭ X, Čižinská S, Krejčí J, Janoch T. Biological water denitrification- a review. Enzyme Microb Technol. 1992;14:170-183.

[8] Zoppas FM, Marchesini FA, Devard A, Bernardes AM, Miró EE. Controlled deposition of Pd and In on carbon fibers by sequential electroless plating for the catalytic reduction of nitrate in water. Catal Commun. 2016;78:59-63.

[9] de Vooys ACA, Van Santen RA, Van Veen JAR. Electrocatalytic reduction of $\mathrm{NO}_{3}{ }^{-}$on palladium/copper electrodes. J Mol Catal Chem. 2000;154:203-215.

[10] Barbosa DP, Tchiéta P, Rangel M. do C, Epron F, The use of a cation exchange resin for palladium-tin and palladium-indium catalysts for nitrate removal in water. J Mol Catal Chem. 2013;366:294-302. 
[11] Prüsse U, Vorlop K-D. Supported bimetallic palladium catalysts for water-phase nitrate reduction. J Mol Catal. Chem. 2001;173:313-328.

[12] Baker RW. Membrane technology and applications. [place unknown]: John Wiley \& Sons; 2004.

[13] Rowe DR, Abdel-Magid I M. Handbook of wastewater reclamation and reuse. [place unknown]:CRC Press;1995.

[14] Menkouchi Sahli MA, Annouar S, Mountadar M, Soufiane A, Elmidaoui A. Nitrate removal of brackish underground water by chemical adsorption and by electrodialysis. Desalination 2008; 227:327-333.

[15] Kim YJ, Lee K, Cha HY, Yoo KM, Jeon CS, Kim HJ, Kim D, Park KY. Electrolytic denitrification with an ion-exchange membrane in groundwater. Water Sei Technol Water Supply 2015;15:1320-25.

[16] Genders JD, Hartsough D, Hobbs DT. Electrochemical reduction of nitrates and nitrites in alkaline nuclear waste solutions. J Appl Electrochem. 1996;26:1-9.

[17] Mattarozzi L, Cattarin S, Comisso N, Guerriero P, Musiani M, Vázquez-Gómez L, E Verlato. Electrochemical reduction of nitrate and nitrite in alkaline media at $\mathrm{CuNi}$ alloy electrodes, Electrochim Acta. 2013;89:488-496.

[18] Li M, Feng C, Zhang Z, Yang S, Sugiura N. Treatment of nitrate contaminated water using an electrochemical method. Bioresour Technol. 2010;101:6553-6557.

[19] Reyter D, Bélanger D, Roué L. Nitrate removal by a paired electrolysis on copper and $\mathrm{Ti} / \mathrm{IrO} 2$ coupled electrodes - Influence of the anode/cathode surface area ratio. Water Res. 2010; 44:1918-26.

[20] Bouzek K, Paidar M, Sadilkova A, Bergmann H. Electrochemical reduction of nitrate in weakly alkaline solutions. J Appl Electrochem. 2001;31:1185-1193.

[21] Dash BP, Chaudhari S. Electrochemical denitrificaton of simulated ground water. Water Res. 2005;39: 4065-4072.

[22] Lin Y-F, Jing S-R., Lee D-Y, Wang T-W. Nutrient removal from aquaculture wastewater using a constructed wetlands system. Aquaculture. 2002;209:169-184.

[23] Mook WT, Chakrabarti MH, Aroua MK, Khan GMA, Ali BS, Islam MS, Abu Hassan MA. Removal of total ammonia nitrogen (TAN), nitrate and total organic carbon (TOC) from 
aquaculture wastewater using electrochemical technology: A review. Desalination. 2012;285:113.

[24] Prasad PKR, Priya MN, Palanivelu K. Nitrate removal from groundwater using electrolytic reduction method. Indian J Chem Technol. 2005;12:164-169.

[25] Couto AB, Oishi SS, Ferreira NG. Enhancement of nitrate electroreduction using BDD anode and metal modified carbon fiber cathode. J of Indust and Eng Chem. 2016;39:210-217.

[26] Bosko ML, Rodrigues MAS, Ferreira J Z, Miró EE, Bernardes AM. Nitrate reduction of brines from water desalination plants by membrane electrolysis. J Membr Sci. 2014;451:276284.

[27] Lacasa E, Cañizares P, Llanos J, Rodrigo MA. Removal of nitrates by electrolysis in nonchloride media: Effect of the anode material. Sep Purif Technol. 2011;80:592-599.

[28] Greenwood Norman N, Earnshaw A. Chemistry of the Elements. New York: Pergamon Press: Oxford; 1984.

[29] Wisniewski C, Persin F, Cherif T, Sandeaux R, Grasmick A, Gavach C, Lutin F. Use of a membrane bioreactor for denitrification of brine from an electrodialysis process. Desalination. 2002;149:331-336.

[30] Wisniewski C, Persin F, Cherif T, Sandeaux R, Grasmick A, Gavach C. Denitrification of drinking water by the association of an electrodialysis process and a membrane bioreactor: feasibility and application. Desalination. 2001;139:199-205.

[31] Hell F, Lahnsteiner J, Frischherz H, Baumgartner G. Experience with full-scale electrodialysis for nitrate and hardness removal. Desalination. 1998;117:173-180.

[32] Lee JD. [Inorganic chemistry not so concise] São Paulo: Edgarg Blücher Ltda; 1999. Portuguese.

[33] Marchesini FA, Irusta S, Querini C, Miró E. Spectroscopic and catalytic characterization of $\mathrm{Pd}-$-In and $\mathrm{Pt}-\mathrm{In}$ supported on $\mathrm{Al}_{2} \mathrm{O}_{3}$ and $\mathrm{SiO}_{2}$, active catalysts for nitrate hydrogenation. Appl Cat A: General. 2008;348:60-70.

[34] dos Reis JAT, Mendonça ASF. [Technical analysis of the new Brazilian stanfards for ammonia in effluents and water bodies] A. Eng Sanit Ambiental. 2009;14:353-362.Portuguese.

[35] Strathmann H. Chapter 6- Electrodialysis and related processes. Membrane Scienc. and Technol. 1995:213-281. 
[36] Buzzi DC, Viegas LS, Rodrigues MAS, Bernardes AM, Tenório JAS. Water recovery from acid mine drainage by electrodialysis. Miner Eng. 2013;40:82-89.

[37] Moura RCA, Bertuol DA, Ferreira CA, Amado FDR. Study of Chromium Removal by the Electrodialysis of Tannery and Metal-Finishing Effluents. Int J Chem Eng. 2012:1-7.

[38] Meng H, Deng D, Chen S, Zhang G. A new method to determine the optimal operating current (Ilim') in the electrodialysis process. Desalination. 2005;181:101-108.

[39] Pourbaix M. Atlas D’equilibres Electrochimiques. Paris: Gauthier-Villars;1963.

[40] Meyer D, Prien RD, Dellwig O, Waniek JJ, Schulz-Bull DE. Electrode measurements of the oxidation reduction potential in the Gotland Deep using a moored profiling instrumentation. Estuar Coast Shelf Sci. 2014;141:26-36.

[41] Cheng H, Scott K, Christensen PA. Application of a solid polymer electrolyte reactor to remove nitrate ions from wastewater. J Appl Electrochem. 2005;35:551-60.

[42] Sinha $X$. The electrochemical reduction of nitrate in low conductivity aqueous solutions, [master's thesis]. United States: San Jose State University; 2005.

[43] Zumdahl SS. Chemical Principles. Lexington. D.C Heath and Company;1995.

[44] Szpyrkowicz L, Daniele S, Radaelli M, Specchia S. Removal of $\mathrm{NO}_{3}{ }^{-}$from water by electrochemical reduction in different reactor configurations. Appl Catal B Environ. 2006;66: $40-50$.

[45] Dortsiou M, Katsounaros I, Polatides C, Kyriacou G. Influence of the electrode and the pH on the rate and the product distribution of the electrochemical removal of nitrate. Environ Technol. $2013 ; 34: 373-381$

[46] Chen Y-X, Zhang Y, Chen G-H. Appropriate conditions or maximizing catalytic reduction efficiency of nitrate into nitrogen gas in groundwater. Water Res. 2003;37:2489-2495.

[47] Yang D, Feng W, Wu G, Li L, Guan N. Nitrate hydrogenation on Pd-Cu/TiO 2 catalyst prepared by photo-deposition. Catal Today. 2011;175:356-361.

[48] Berndt H, Mönnich I, Lücke B, Menzel M. Tin promoted palladium catalysts for nitrate removal from drinking water. Appl Catal B Environ. 2001;30:111-122.

[49] Zhao Y, Koteswara Rao N Lefferts, L. Adsorbed species on Pd catalyst during nitrite hydrogenation approaching complete conversion. J Catal. 2016;337:102-110. 
[50] Zhao Y, Baeza JA, Koteswara Rao N, Calvo L, Gilarranz MA, Li YD, Lefferts L.

Unsupported PVA- and PVP-stabilized Pd nanoparticles as catalyst for nitrite hydrogenation in aqueous phase. J Catal. 2014;318:162-169.

[51] Zhao W, Zhu X, Wang Y, Ai Z, Zhao D. Catalytic reduction of aqueous nitrates by metal supported catalysts on Al particles. Chem Eng J. 2014;254:410-417.

[52] Zhang Z, Xu YP, Shi WX, Wang W, Zhang RJ, Bao X, Zhang B, Li L, Cui FY. Electrochemical-catalytic reduction of nitrate over $\mathrm{Pd}-\mathrm{Cu} / \mathrm{\gamma Al}_{2} \mathrm{O}_{3}$ catalyst in cathode chamber: Enhanced removal efficiency and $\mathrm{N}_{2}$ selectivity. Chem Eng J. 2016;290:201-208. 


\section{Tables with captions:}

Table 1. Concentration of model solutions.

Table 2. Initial and final cell potential and conductivity of the nitrate solutions in the experiments with a current density of $1.1 \mathrm{~mA} \cdot \mathrm{cm}^{-2}$.

Table 3. Concentration of N-Nitrate, N-Nitrite and N-Gaseous compounds for the constant cell potential at $5 \mathrm{~V}$ and $7 \mathrm{~V}$ (nitrate concentration of $600 \mathrm{mg} \cdot \mathrm{L}^{-1}$ ), $\mathrm{T}=28^{\circ} \mathrm{C}$. 
Tables:

Table 2. Concentration of model solutions.

\section{Cathode compartment Anode compartment}

\begin{tabular}{cc}
\hline Nitrate concentration & Sodium sulfate concentration \\
$200 \mathrm{mg} . \mathrm{L}^{-1}$ & $700 \mathrm{mg} . \mathrm{L}^{-1}$ \\
$600 \mathrm{mg} . \mathrm{L}^{-1}$ & $1400 \mathrm{mg} . \mathrm{L}^{-1}$ \\
$1000 \mathrm{mg} . \mathrm{L}^{-1}$ & $2000 \mathrm{mg} . \mathrm{L}^{-1}$ \\
\hline
\end{tabular}


Table 2. Initial and final cell potential and conductivity of the nitrate solutions in the experiments with a current density of $1.1 \mathrm{~mA} \cdot \mathrm{cm}^{-2}$.

\begin{tabular}{c|c|c|c|c|c}
\hline \multirow{2}{*}{$\begin{array}{c}\text { Nitrate } \\
\text { solution }\end{array}$} & \multicolumn{2}{|c|}{$\begin{array}{c}\text { Cell potential } \\
(\mathbf{V})\end{array}$} & \multirow{2}{*}{$\begin{array}{c}\text { Cell } \\
\text { Compartment }\end{array}$} & \multicolumn{2}{c}{$\begin{array}{c}\text { Conductivity } \\
\left(\boldsymbol{\mu S . c m} \mathbf{S m}^{-1}\right)\end{array}$} \\
\cline { 2 - 4 } & Initial & Final & & Initial & Final \\
\hline \multirow{2}{*}{$200 \mathrm{mg} . \mathrm{L}^{-1}$} & $13 \pm 0.4$ & $7 \pm 0.6$ & Cathode & 416 & 1160 \\
\cline { 5 - 6 } & & & Anode & 1080 & 2039 \\
\hline $600 \mathrm{mg} . \mathrm{L}^{-1}$ & \multirow{2}{*}{$7 \pm 0.2$} & \multirow{2}{*}{$5 \pm 0.1$} & Cathode & 984 & 2094 \\
\cline { 5 - 6 } & & & Anode & 1941 & 3015 \\
\hline $1000 \mathrm{mg} . \mathrm{L}^{-1}$ & $6 \pm 0.3$ & \multirow{2}{*}{$5 \pm 0.4$} & Cathode & 1563 & 3140 \\
\cline { 5 - 6 } & & & Anode & 2463 & 4140 \\
\hline
\end{tabular}


Table 3. Concentration of N-Nitrate, N-Nitrite and N-Gaseous compounds for the constant cell potential at $5 \mathrm{~V}$ and $7 \mathrm{~V}$ (nitrate concentration of $600 \mathrm{mg} \cdot \mathrm{L}^{-1}$ ), $\mathrm{T}=28^{\circ} \mathrm{C}$.

\begin{tabular}{|c|c|c|c|c|c|}
\hline Time (h) & $\begin{array}{c}\text { Cell } \\
\text { Potential }\end{array}$ & $\begin{array}{c}\text { Final Current } \\
\text { density } \\
\left(\mathbf{m A} \cdot \mathrm{cm}^{-2}\right)\end{array}$ & $\begin{array}{c}\text { N-Nitrate } \\
\left(\mathrm{mg}^{-1} \mathrm{~L}^{-1}\right)\end{array}$ & $\begin{array}{l}\text { N-Nitrite } \\
\left(\mathrm{mg} \cdot \mathrm{L}^{-1}\right)\end{array}$ & $\begin{array}{c}\text { N-Gaseous } \\
\text { Compounds } \\
\left(\mathrm{mg.L}^{-1}\right)\end{array}$ \\
\hline 6 & \multirow{2}{*}{$5 \mathrm{~V}$} & $1.42 \pm 0.05$ & $117 \pm 3$ & $19 \pm 1$ & $0.3 \pm 0$ \\
\hline 12 & & $1.61 \pm 0.36$ & $105 \pm 3$ & $31 \pm 3$ & $0.4 \pm 0$ \\
\hline 6 & \multirow{2}{*}{$7 \mathrm{~V}$} & $2.92 \pm 0.06$ & $80 \pm 5$ & $40 \pm 12$ & $16 \pm 8$ \\
\hline 12 & & $3.87 \pm 0.12$ & $47 \pm 2$ & $65 \pm 1$ & $23 \pm 2$ \\
\hline
\end{tabular}




\section{Figures captions:}

Figure 1. Flow chart of the methodology used in the current work.

Figure 2. Design of cell A to electroreduction of nitrate.

Figure 3. Design of cell B to electroreduction of nitrate.

Figure 4. Scheme of cell A used to obtain the current-voltage curves.

Figure 5. Current-voltage curves for the cationic membrane in contact with the nitrate solution of 200, 600 and $1000 \mathrm{mg} \cdot \mathrm{L}^{-1}$.

Figure 6. Data of polarization curve of the cationic membrane for solution of $600 \mathrm{mg} \cdot \mathrm{L}^{-1}$ of $\mathrm{NO}_{3}$, current density vs cathode potential and cell potential.

Figure 7. $\mathrm{pH}$ variation using the nitrate concentration of $600 \mathrm{mg} \cdot \mathrm{L}^{-1}$.

Figure 8. Concentration of N-Nitrate, N-Nitrite and N-Gaseous compounds for the nitrate concentration of $600 \mathrm{mg} . \mathrm{L}^{-1}(\mathrm{~A}), 1000 \mathrm{mg} . \mathrm{L}^{-1}$ (B) and $200 \mathrm{mg} \cdot \mathrm{L}^{-1}(\mathrm{C})$, current density of $1.1 \mathrm{~mA} \cdot \mathrm{cm}^{-2}, \mathrm{~T}=28^{\circ} \mathrm{C}$.

Figure 9. Concentration of N-Nitrate, N-Nitrite and N-Gaseous compounds for the nitrate concentration of $600 \mathrm{mg} \cdot \mathrm{L}^{-1}$ and current density of $2.1 \mathrm{~mA} . \mathrm{cm}^{-2}, \mathrm{~T}=28^{\circ} \mathrm{C}$.

Figure 10. Concentration of N-Nitrate, N-Nitrite and N-Gaseous compounds for the nitrate concentration of $600 \mathrm{mg} . \mathrm{L}^{-1}$ and reduced flow with a current density of $1.1 \mathrm{~mA} \cdot \mathrm{cm}^{-2}, \mathrm{~T}=28^{\circ} \mathrm{C}$. Figure 11. Effect of $\mathrm{pH}$ control on the reduction of nitrate using the nitrate solution of $600 \mathrm{mg} . \mathrm{L}^{-1}$ after 12 hours of experiment, $\mathrm{T}=28^{\circ} \mathrm{C}$.

Figure 12. Electrochemical experiments using cell B with and without catalyst (without $\mathrm{pH}$ control and nitrate concentration of $\left.600 \mathrm{mg} \cdot \mathrm{K}^{-1}\right), \mathrm{T}=25^{\circ} \mathrm{C}$.

Figure 13. Electrochemical experiments using cell B with and without catalyst (with 6-6.5 pH control and nitrate concentration of $\left.600 \mathrm{mg} \cdot \mathrm{L}^{-1}\right), \mathrm{T}=25^{\circ} \mathrm{C}$.

Figure 14. Scheme of nitrate electroreduction in cell of two compartments, divided by a cationic membrane. 
Figures:
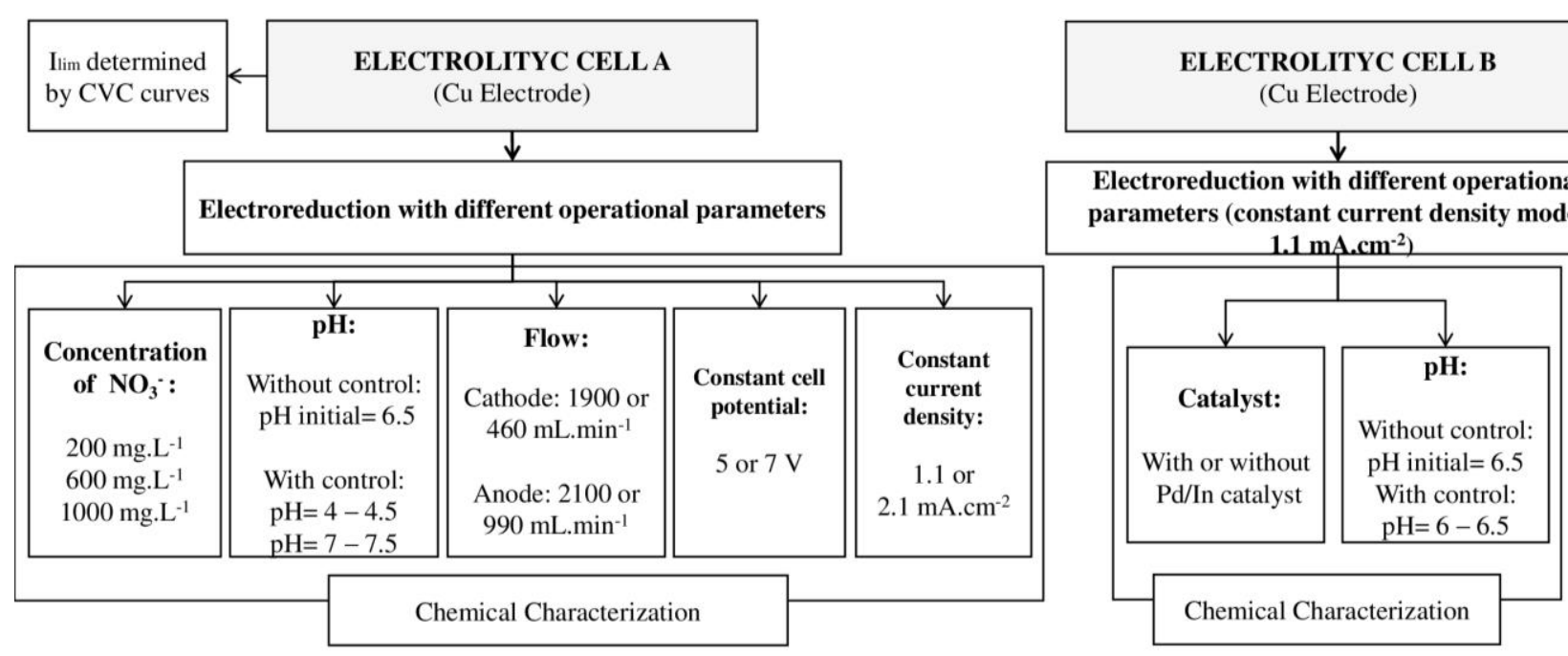

Figure 1. Flow chart of the methodology used in the current work.

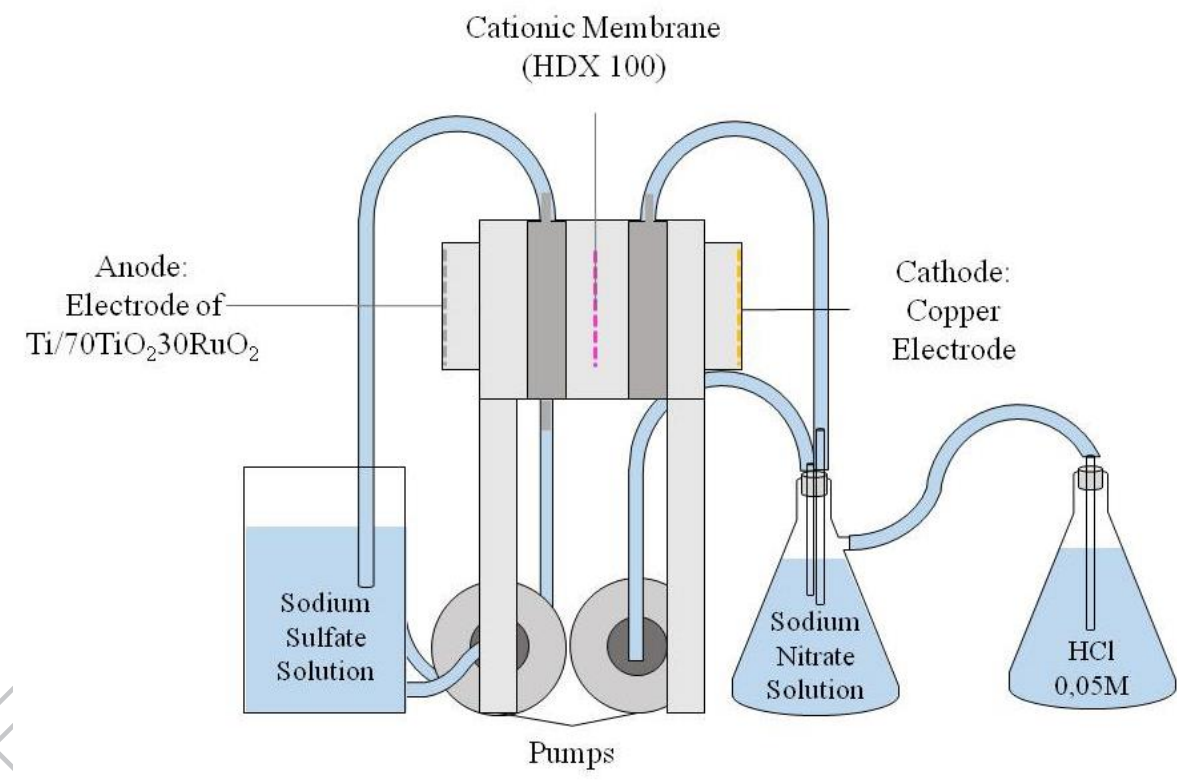

Figure 2. Design of cell A to electroreduction of nitrate. 


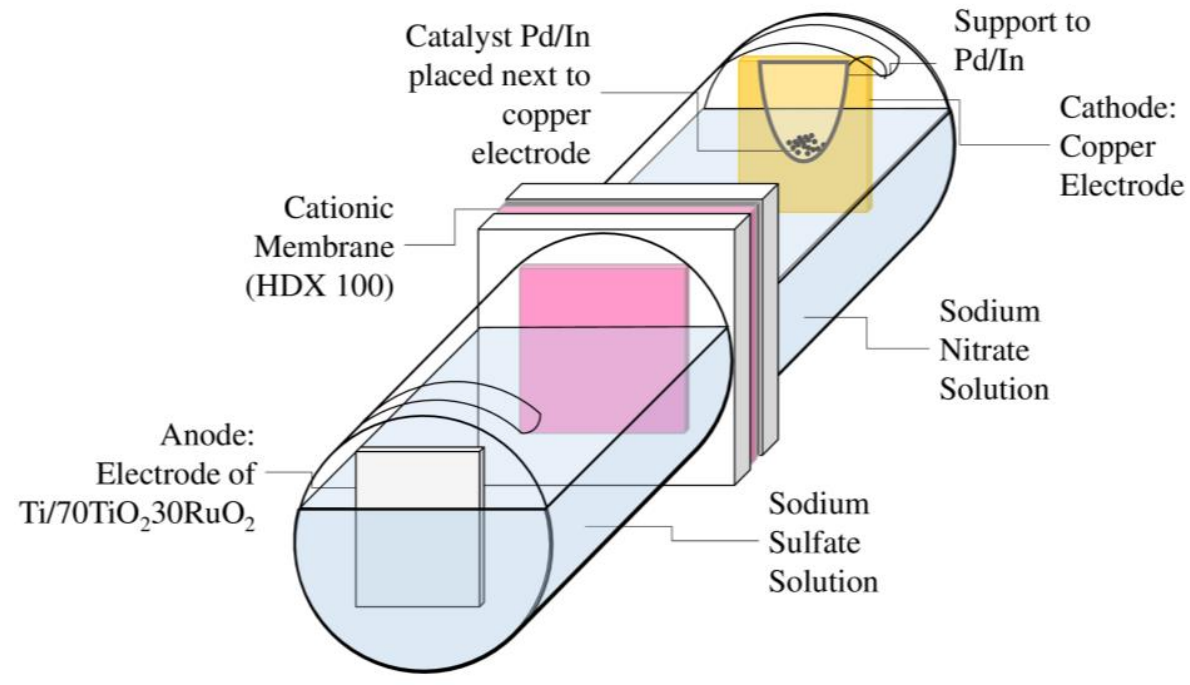

Figure 3. Design of cell B to electroreduction of nitrate.

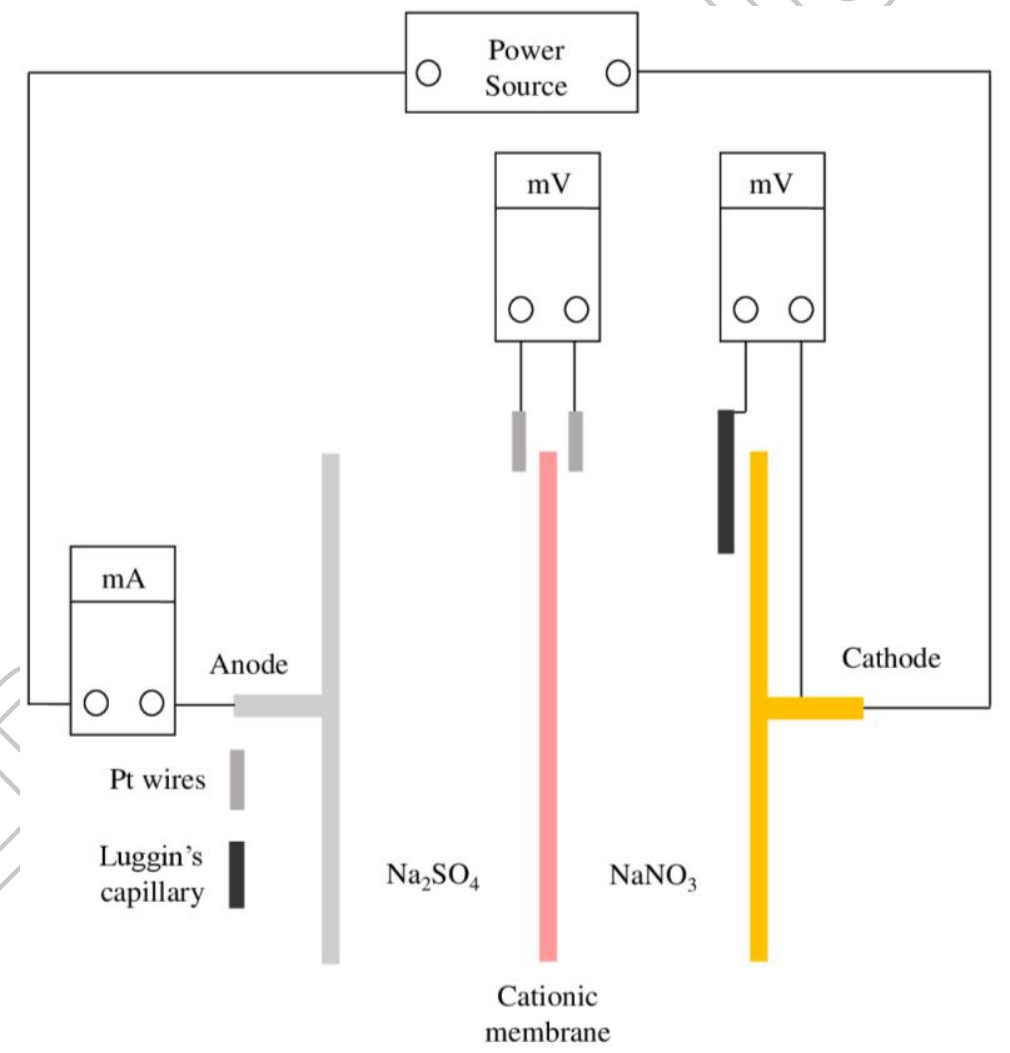

Figure 4. Scheme of cell A used to obtain the current-voltage curves. 


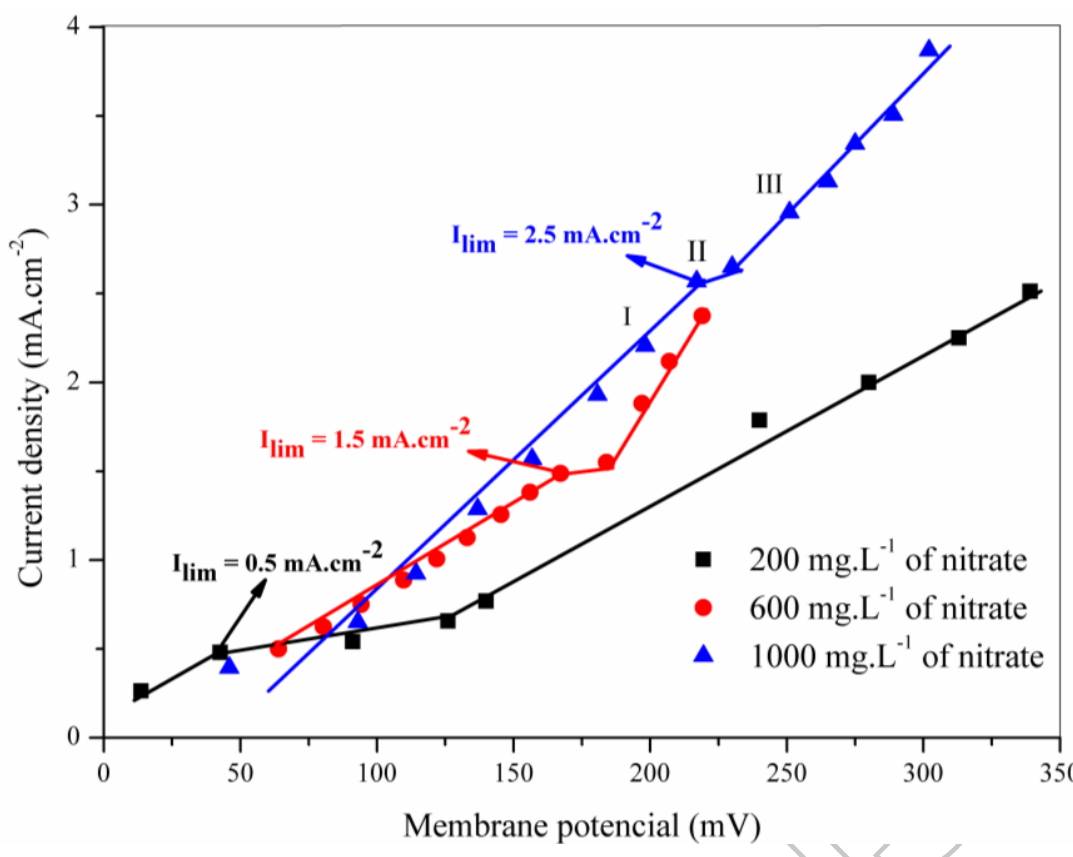

Figure 5. Current-voltage curves for the cationic membrane in contact with the nitrate solution of 200, 600 and $1000 \mathrm{mg} . \mathrm{L}^{-1}$.

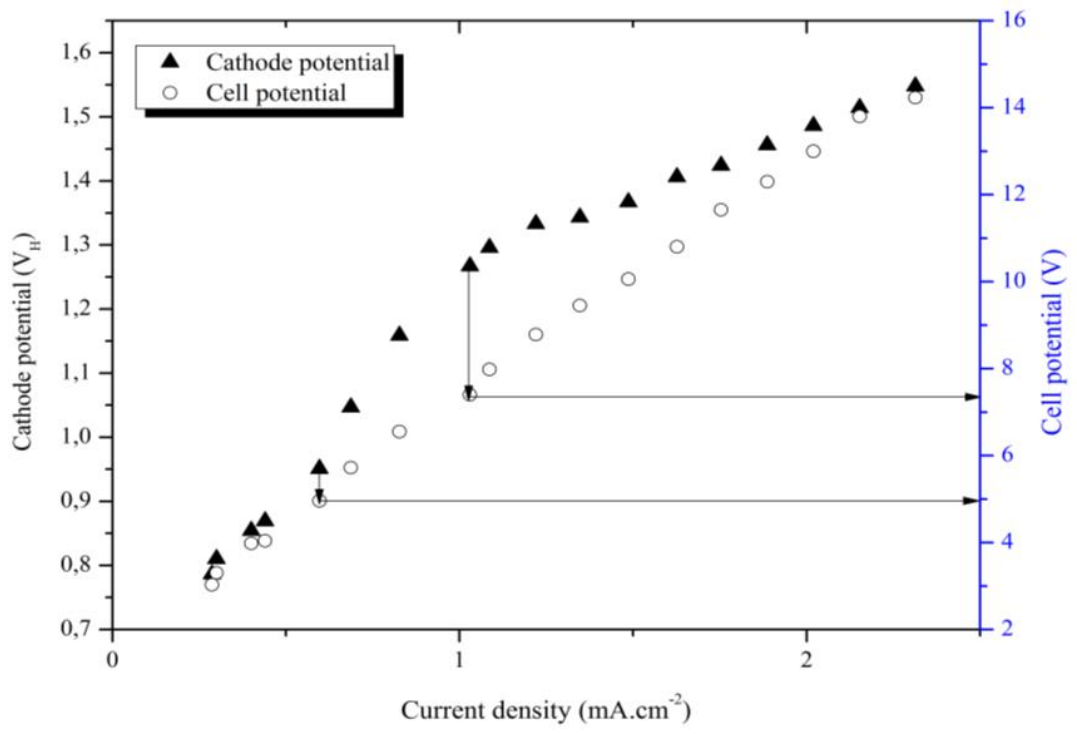

Figure 6. Data of polarization curve of the cationic membrane for solution of $600 \mathrm{mg} . \mathrm{L}^{-1}$ of $\mathrm{NO}_{3}{ }^{-}$ current density vs cathode potential and cell potential. 


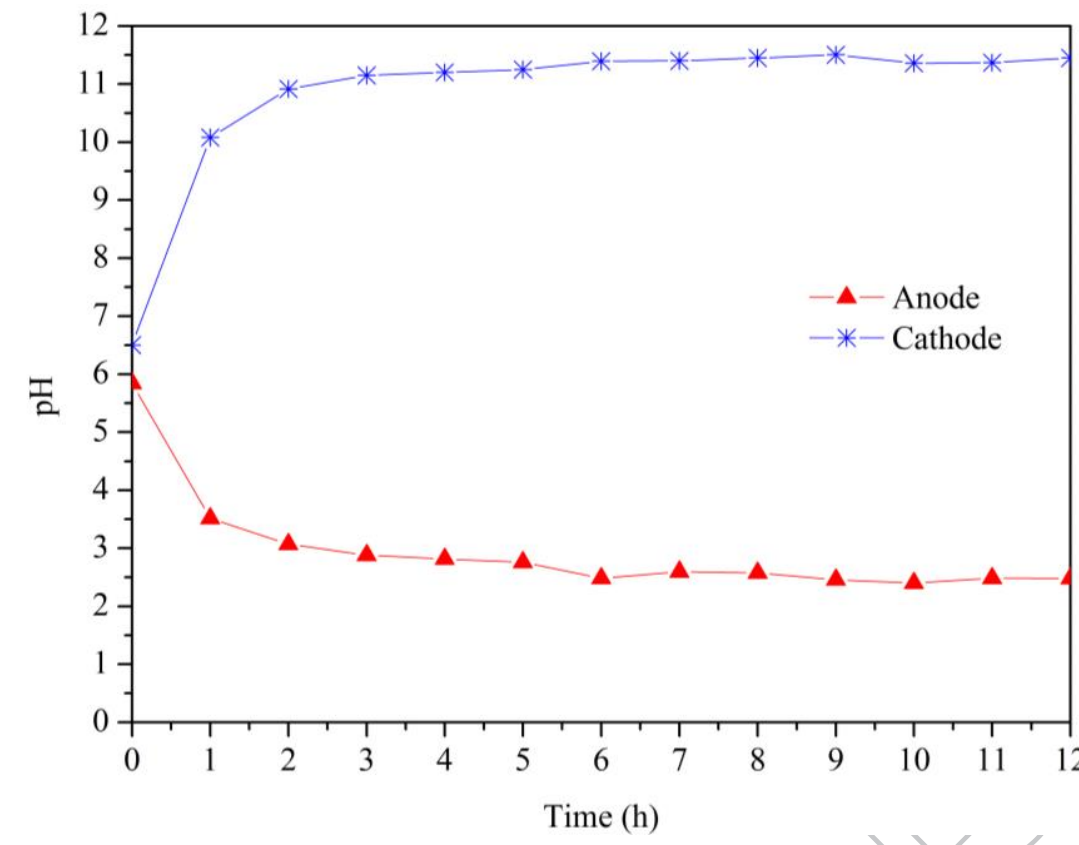

Figure 7. $\mathrm{pH}$ variation using the nitrate concentration of $600 \mathrm{mg} \cdot \mathrm{L}^{-1}$.

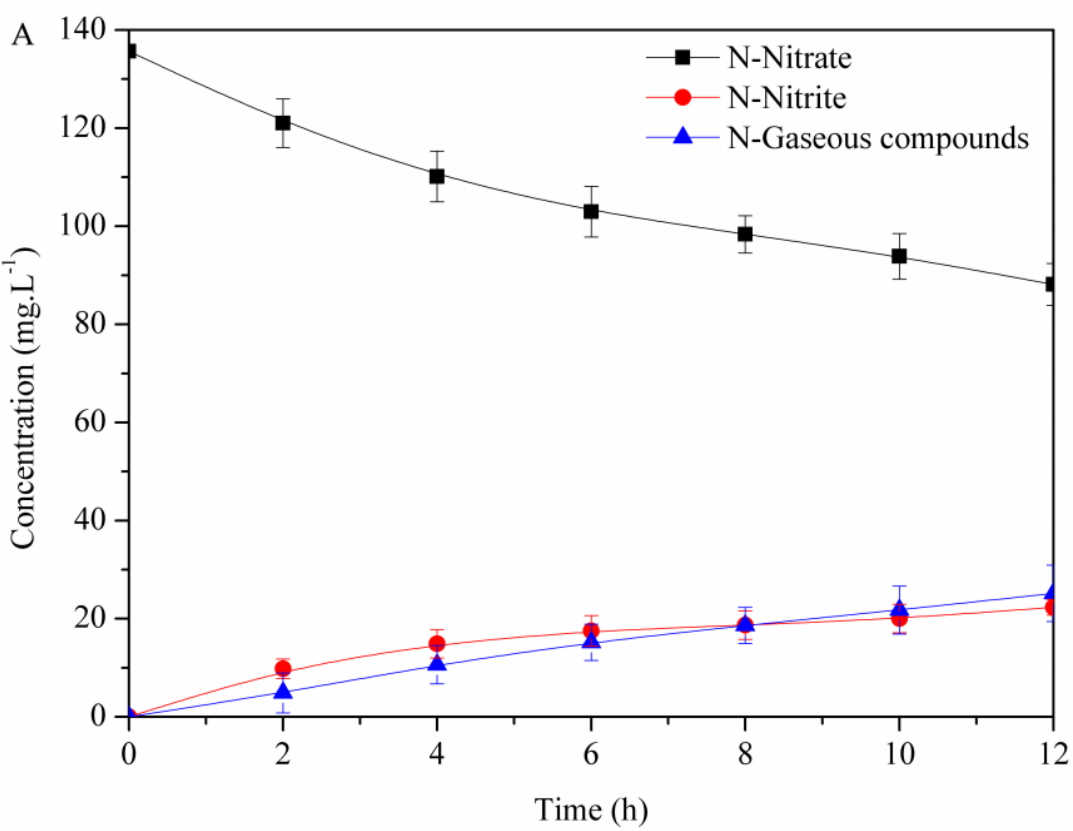



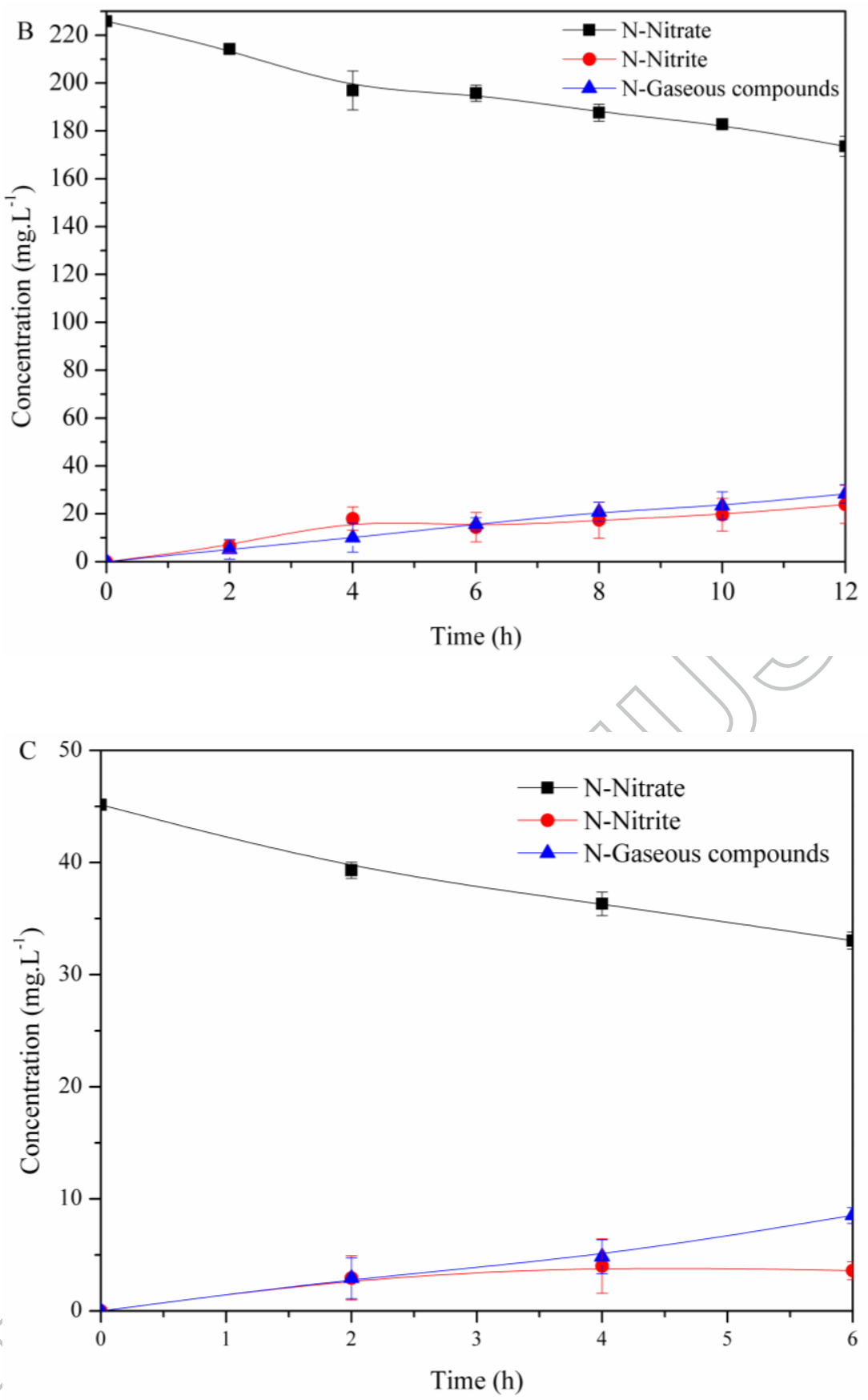

Figure 8. Concentration of N-Nitrate, N-Nitrite and N-Gaseous compounds for the nitrate concentration of $600 \mathrm{mg} \cdot \mathrm{L}^{-1}(\mathrm{~A}), 1000 \mathrm{mg} . \mathrm{L}^{-1}$ (B) and $200 \mathrm{mg} \cdot \mathrm{L}^{-1}(\mathrm{C})$, current density of $1.1 \mathrm{~mA} \cdot \mathrm{cm}^{-2}, \mathrm{~T}=28^{\circ} \mathrm{C}$. 


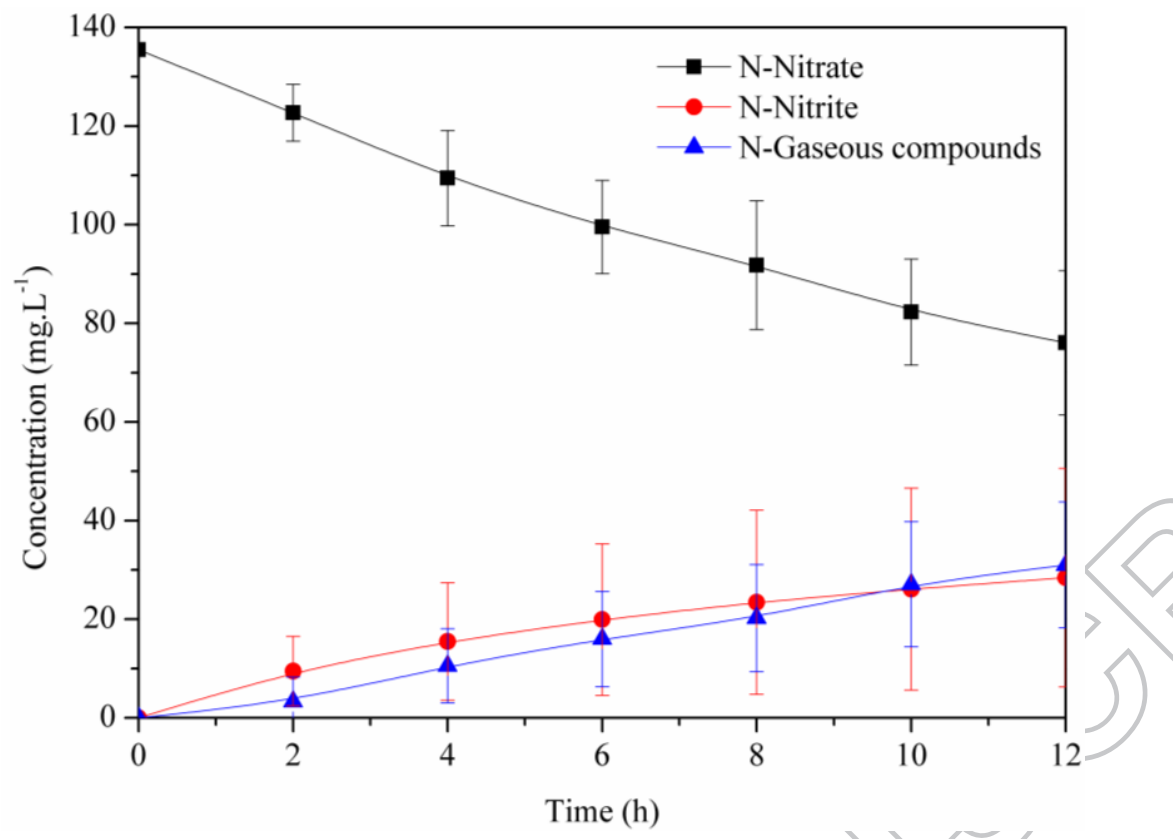

Figure 9. Concentration of N-Nitrate, N-Nitrite and N-Gaseous compounds for the nitrate concentration of $600 \mathrm{mg} \cdot \mathrm{L}^{-1}$ and current density of $2.1 \mathrm{~mA} \cdot \mathrm{cm}^{-2}, \mathrm{~T}=28^{\circ} \mathrm{C}$.

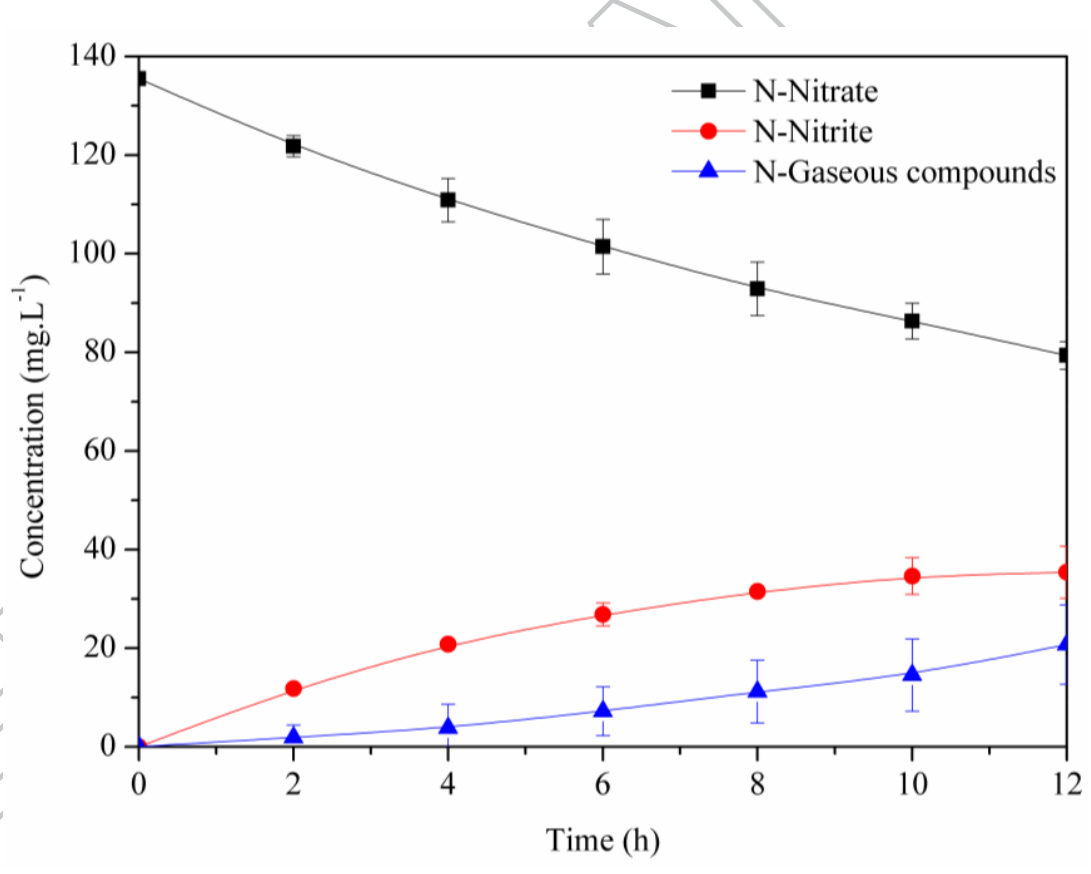

Figure 10. Concentration of N-Nitrate, N-Nitrite and N-Gaseous compounds for the nitrate concentration of $600 \mathrm{mg} \cdot \mathrm{L}^{-1}$ and reduced flow with a current density of $1.1 \mathrm{~mA} \cdot \mathrm{cm}^{-2}, \mathrm{~T}=28^{\circ} \mathrm{C}$. 


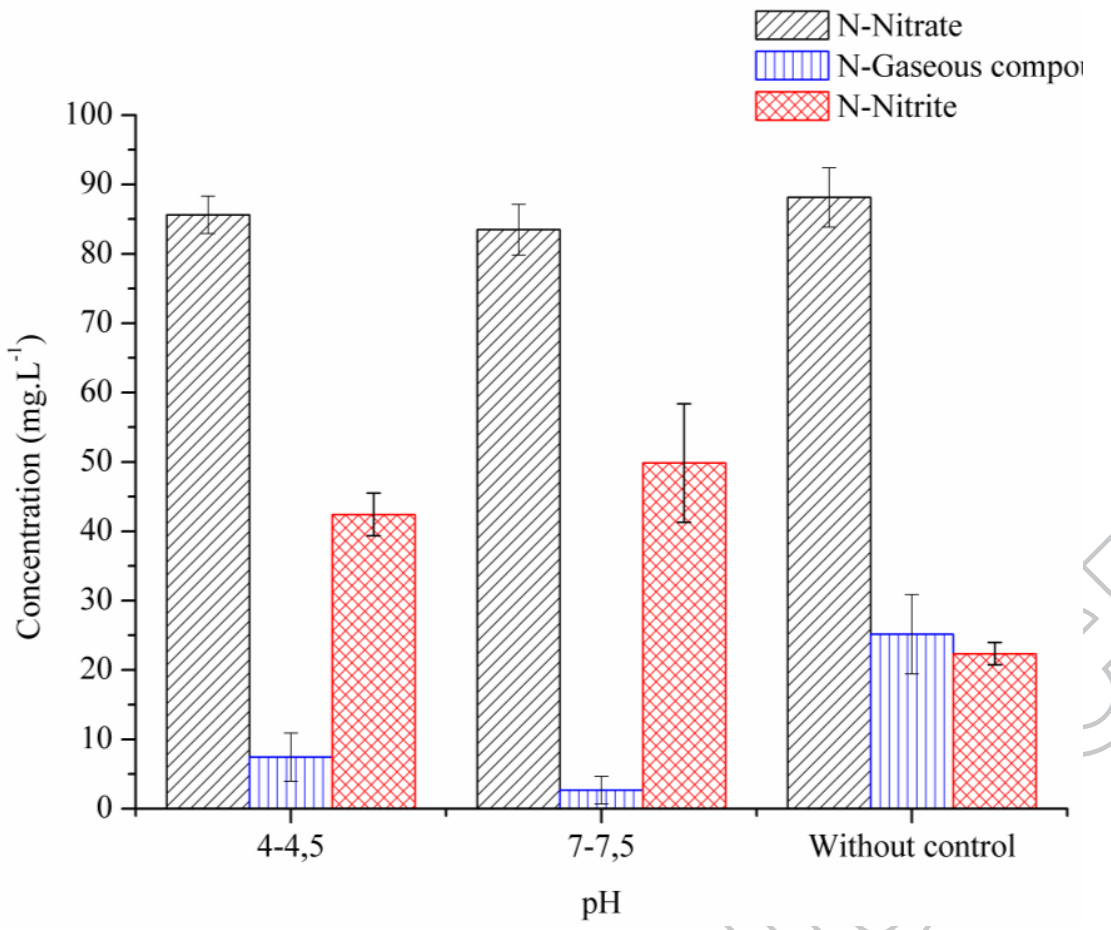

Figure 11. Effect of $\mathrm{pH}$ control on the reduction of nitrate using the nitrate solution of $600 \mathrm{mg} . \mathrm{L}^{-1}$ after 12 hours of experiment, $\mathrm{T}=28^{\circ} \mathrm{C}$.

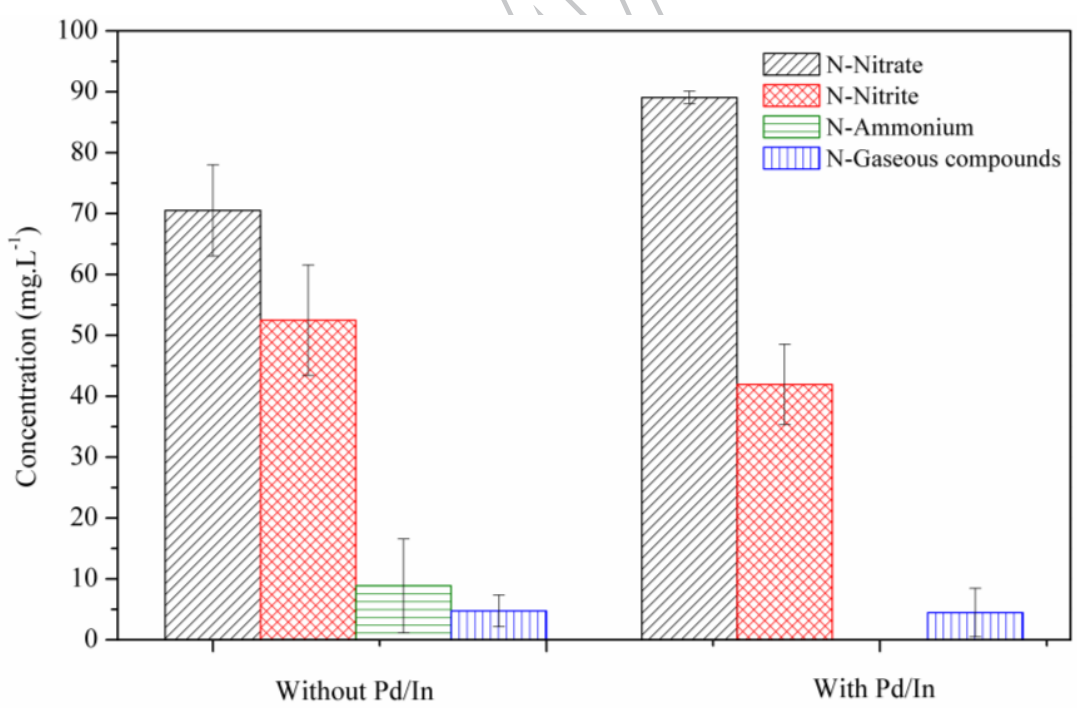

Figure 12. Electrochemical experiments using cell B with and without catalyst (without $\mathrm{pH}$ control and nitrate concentration of $\left.600 \mathrm{mg} \cdot \mathrm{L}^{-1}\right), \mathrm{T}=25^{\circ} \mathrm{C}$. 


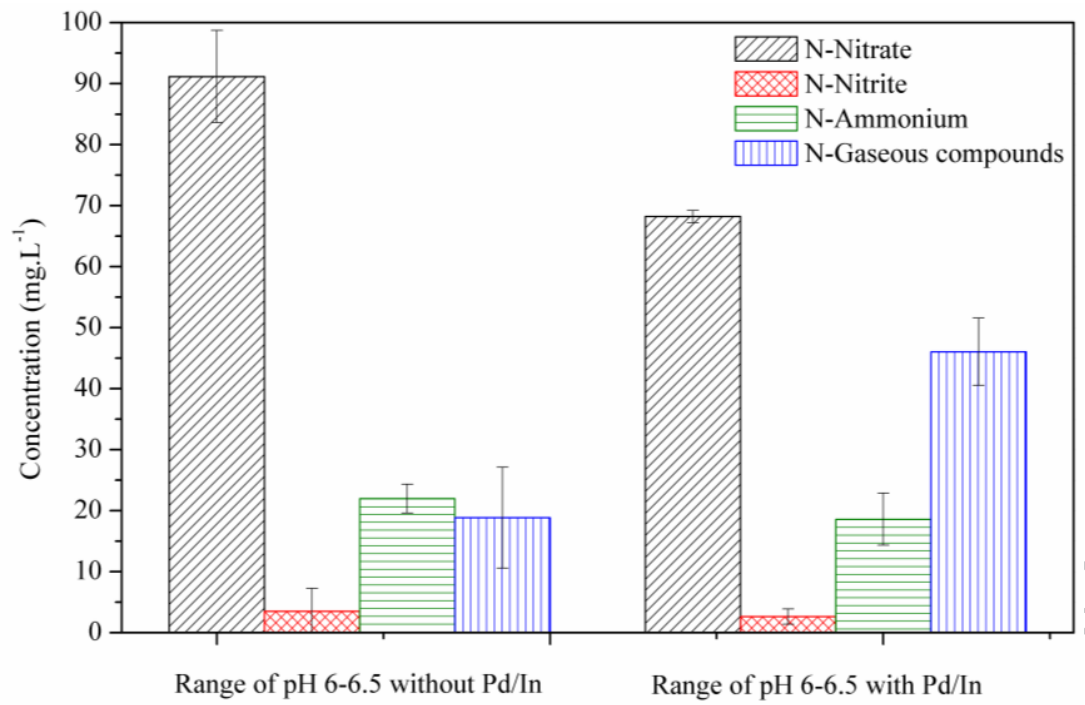

Figure 13. Electrochemical experiments using cell B with and without catalyst (with 6-6.5 pH control and nitrate concentration of $\left.600 \mathrm{mg} \cdot \mathrm{L}^{-1}\right), \mathrm{T}=25^{\circ} \mathrm{C}$.

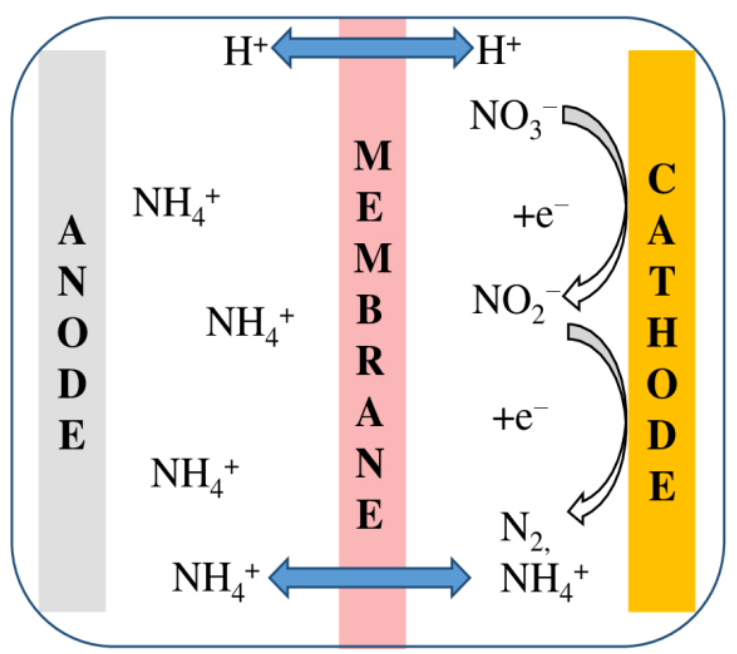

Figure 14. Scheme of nitrate electroreduction in cell of two compartments, divided by a cationic membrane. 


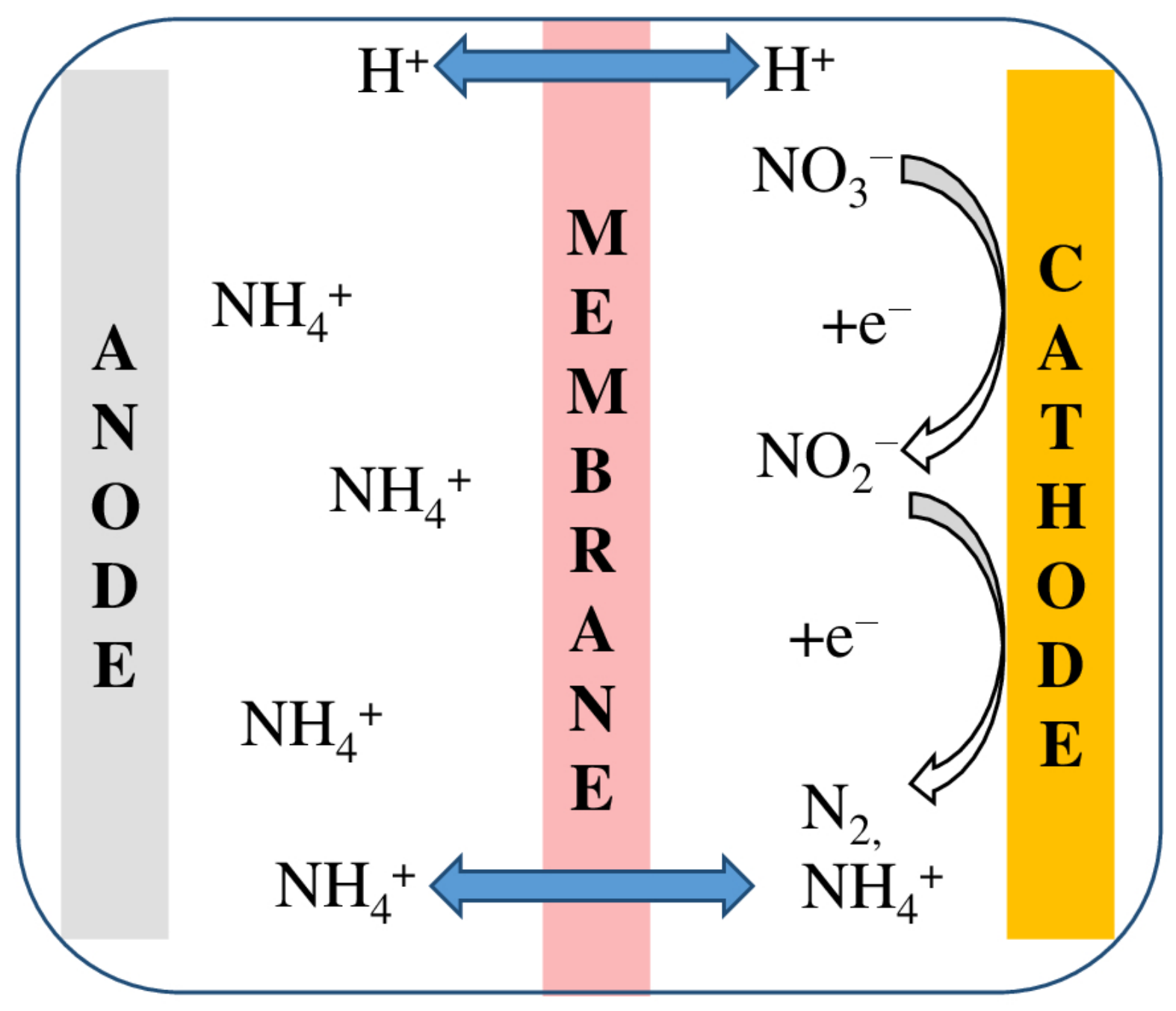




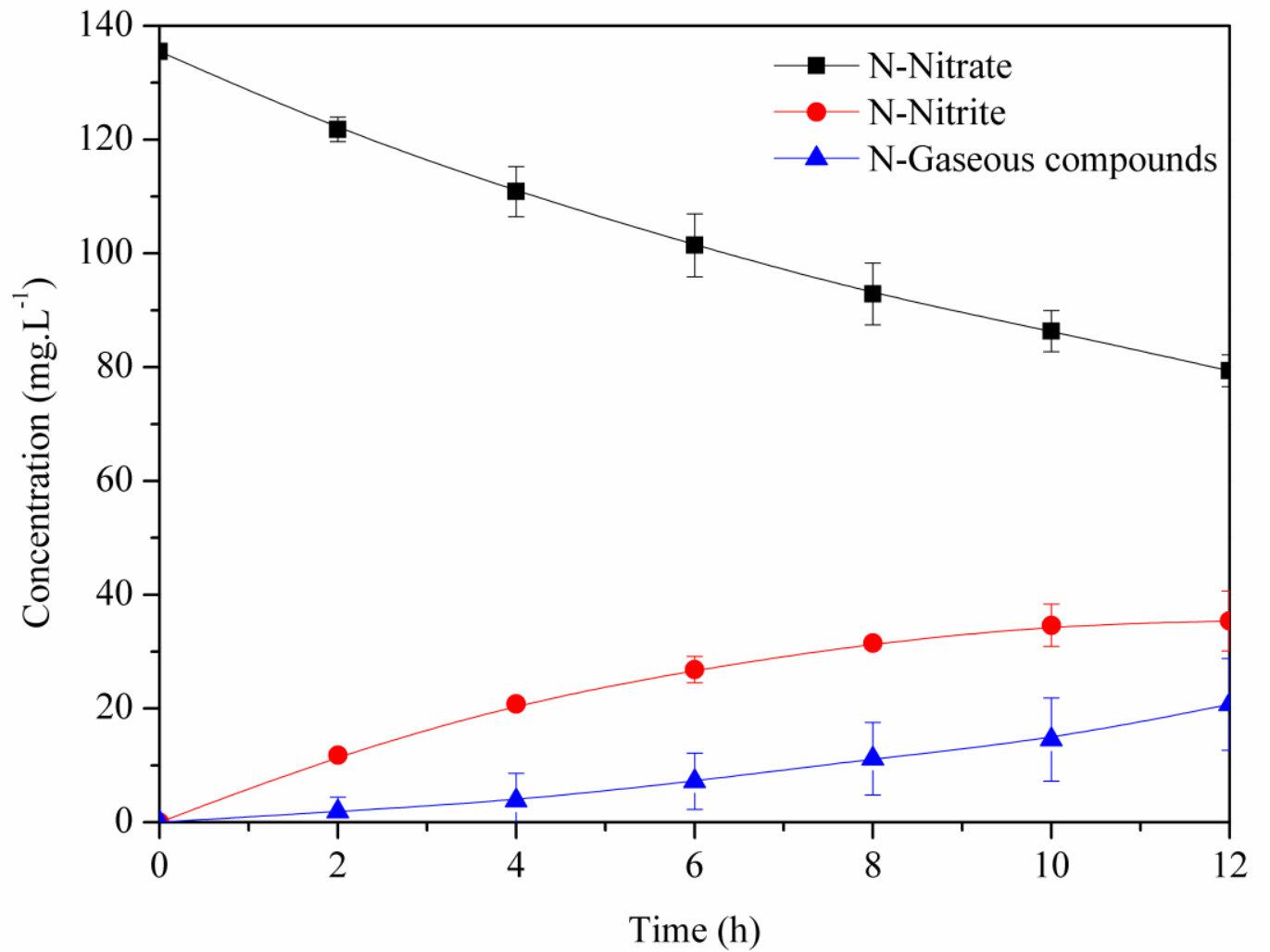

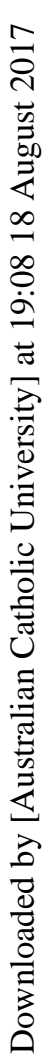




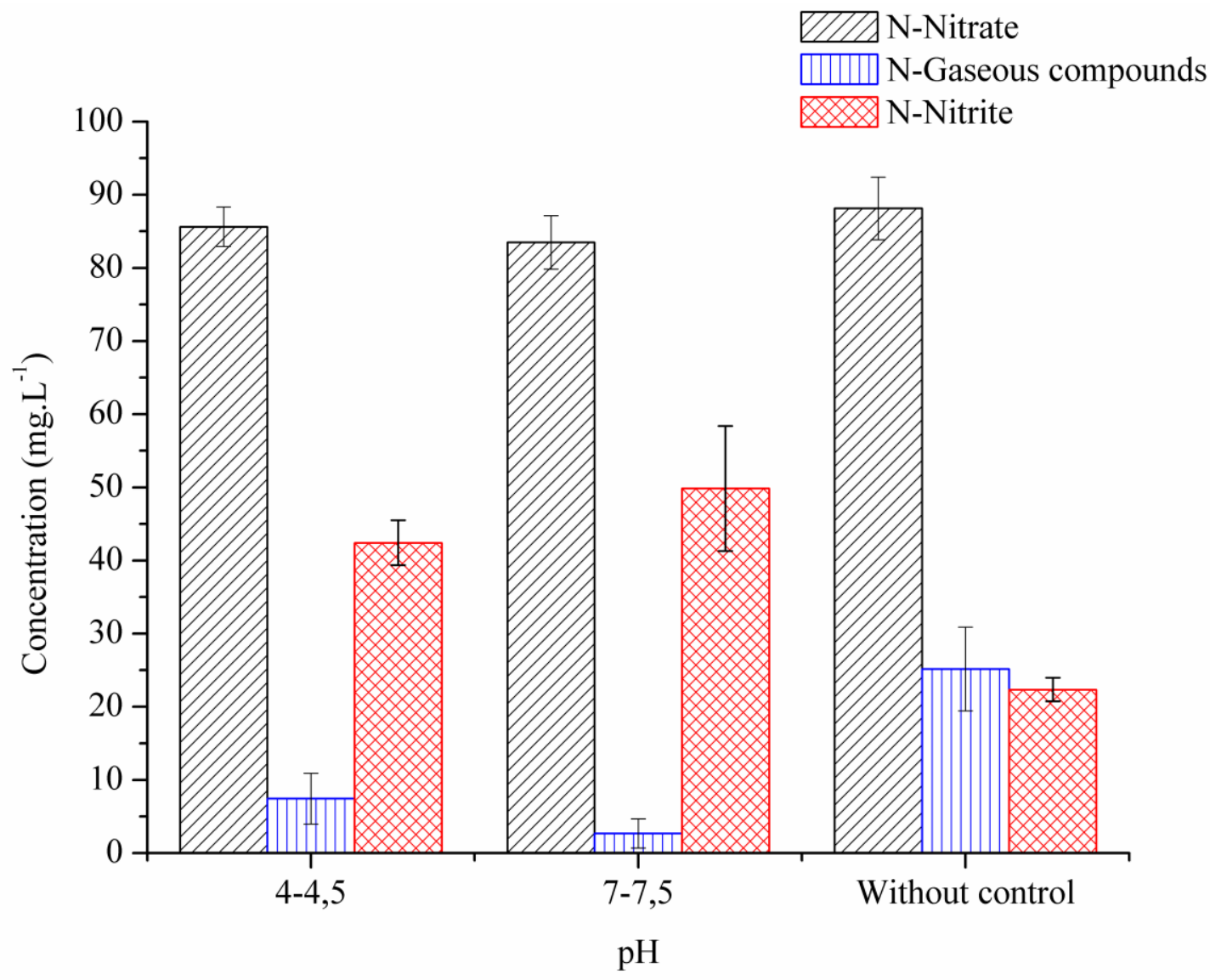




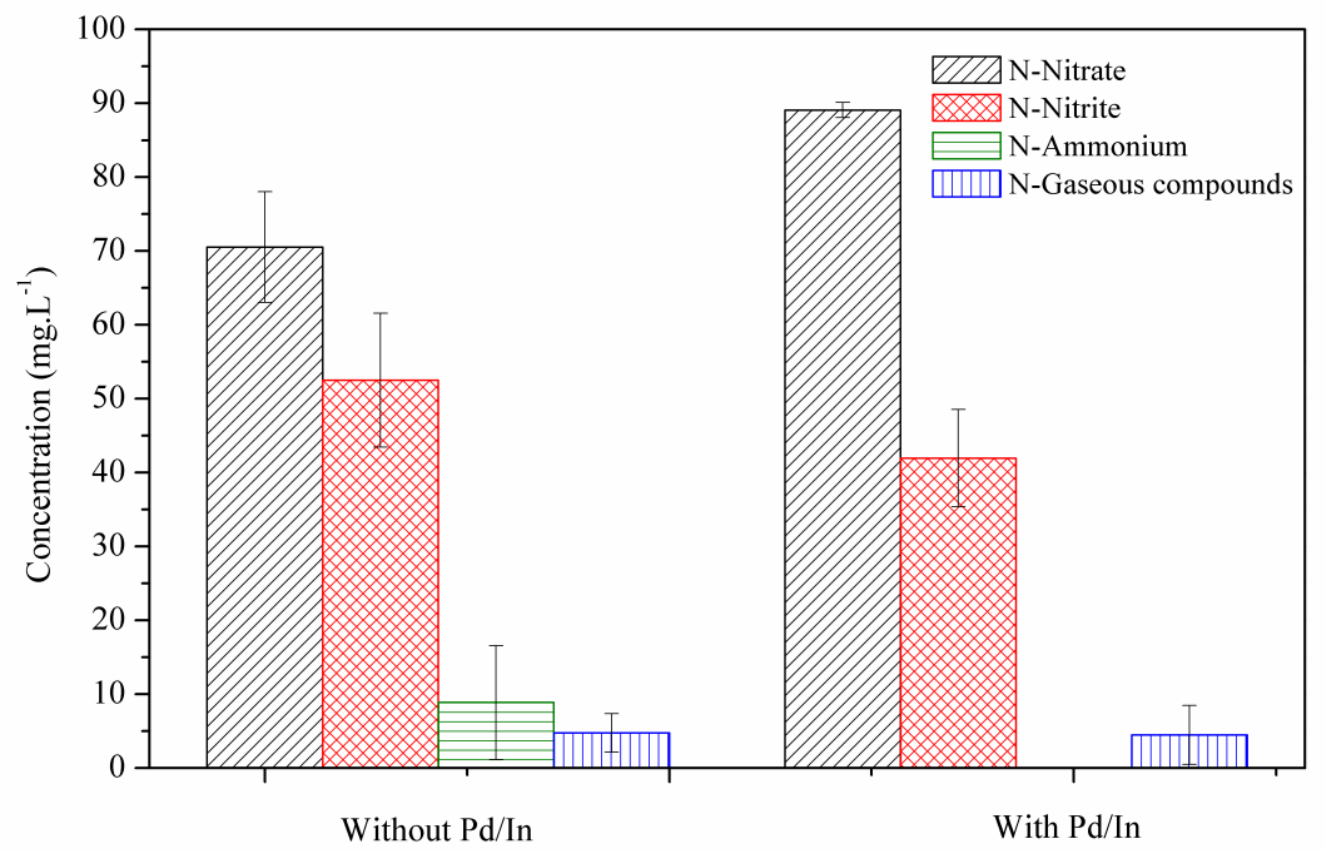




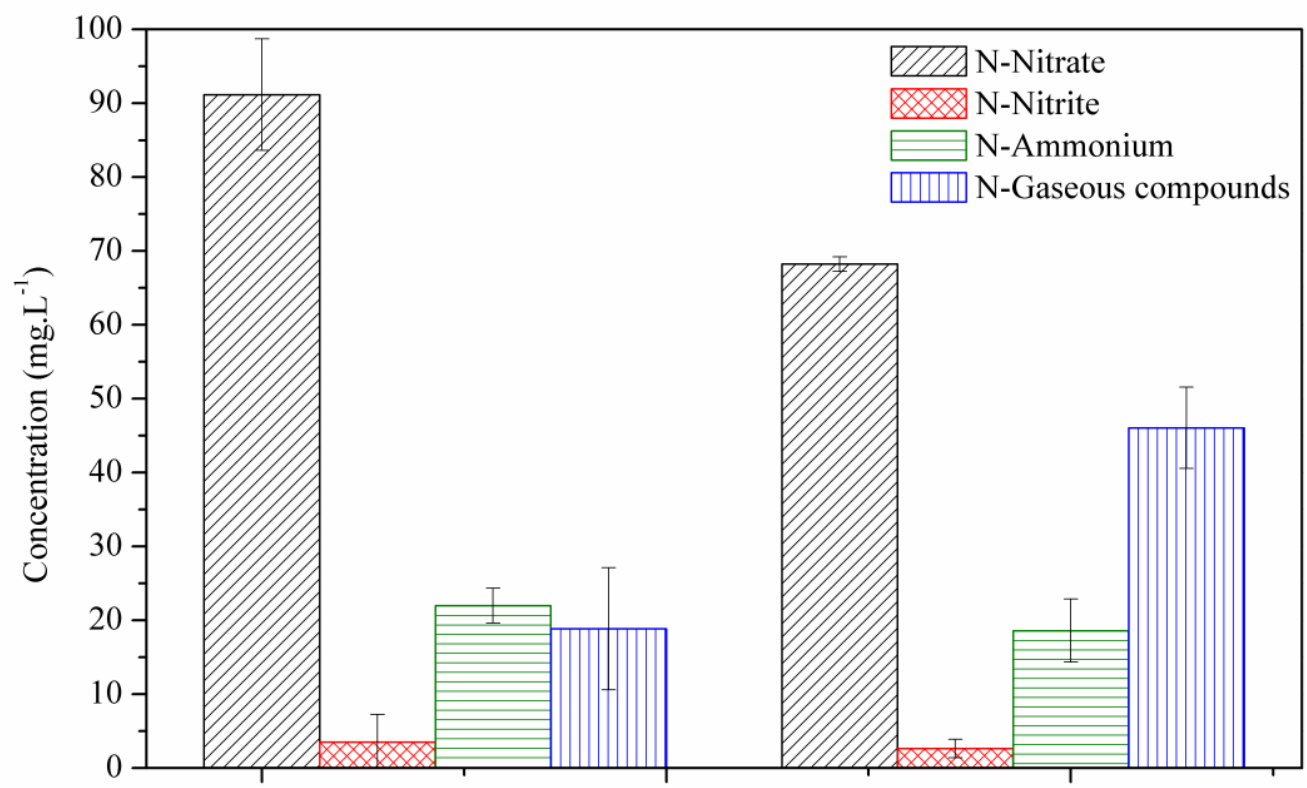

Range of $\mathrm{pH}$ 6-6.5 without $\mathrm{Pd} / \mathrm{In}$

Range of pH 6-6.5 with Pd/In 


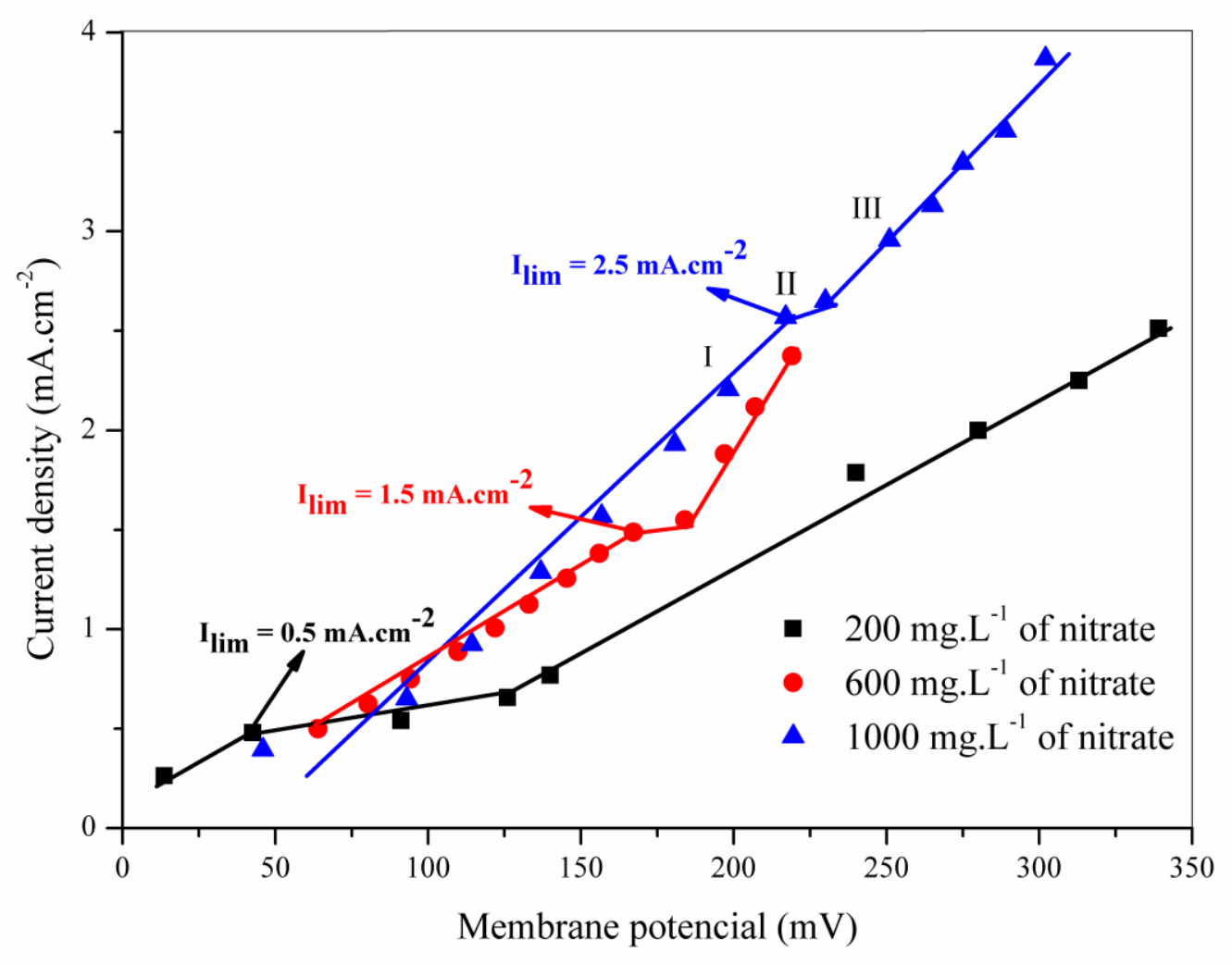




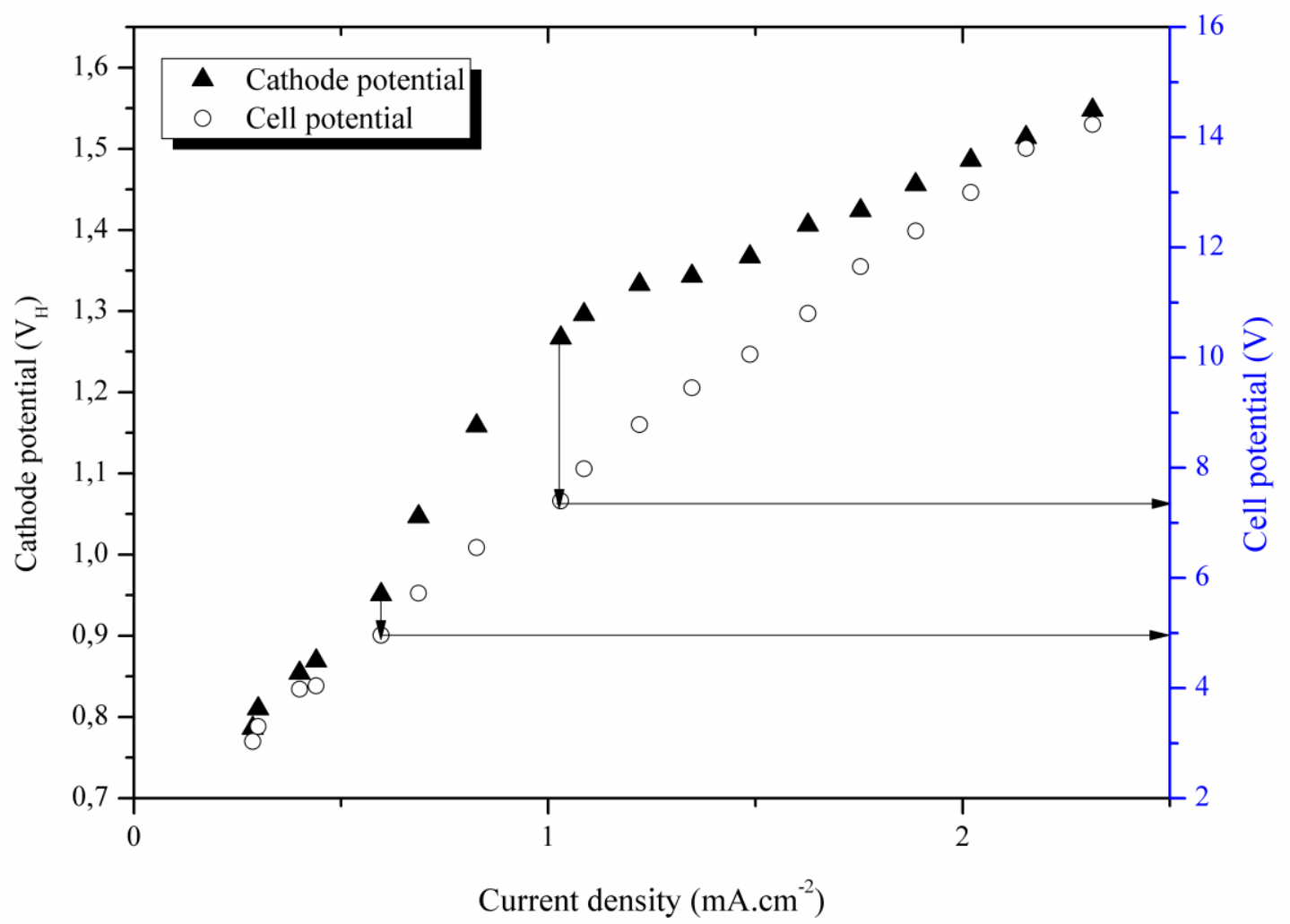




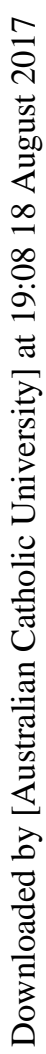

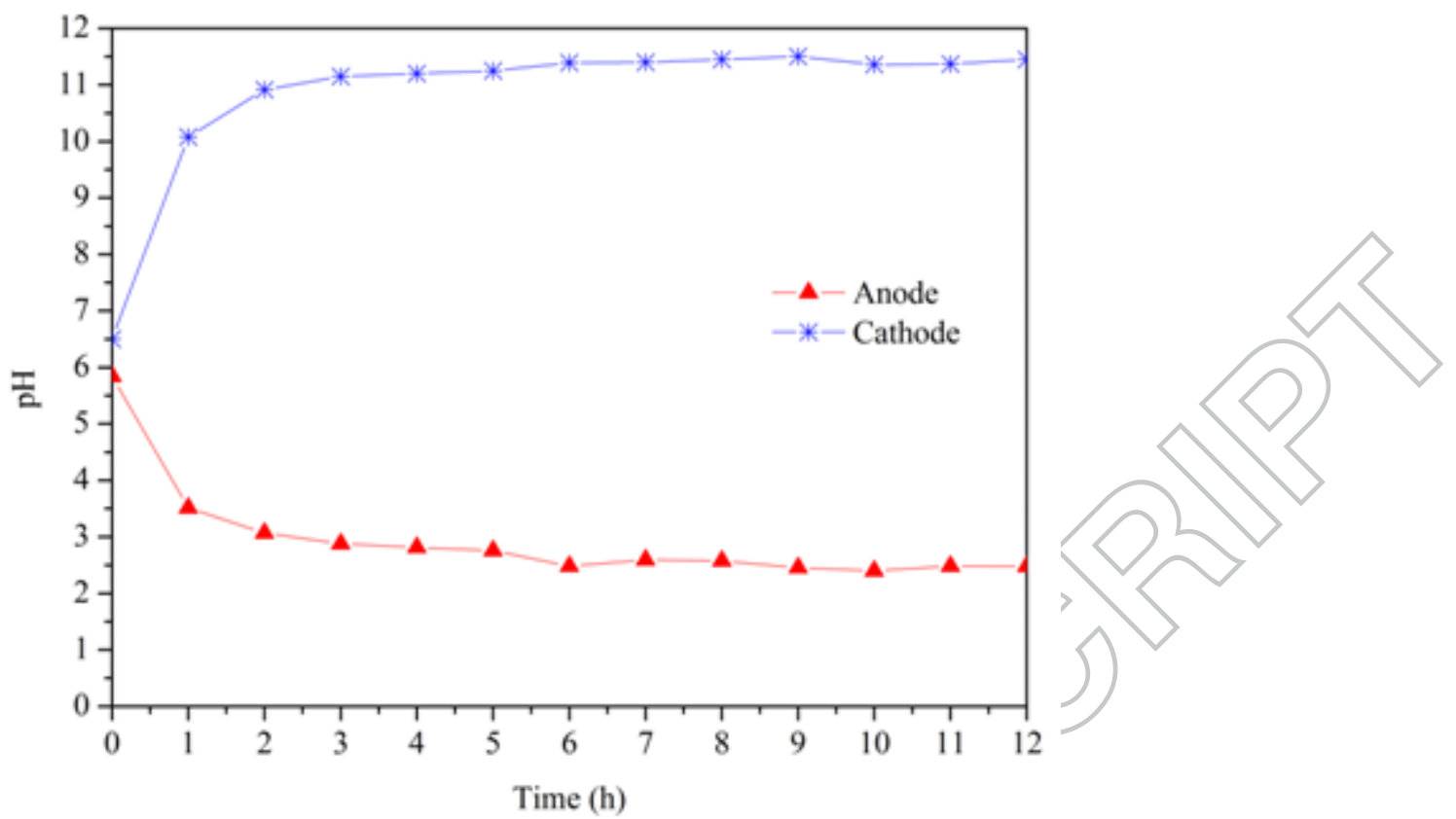




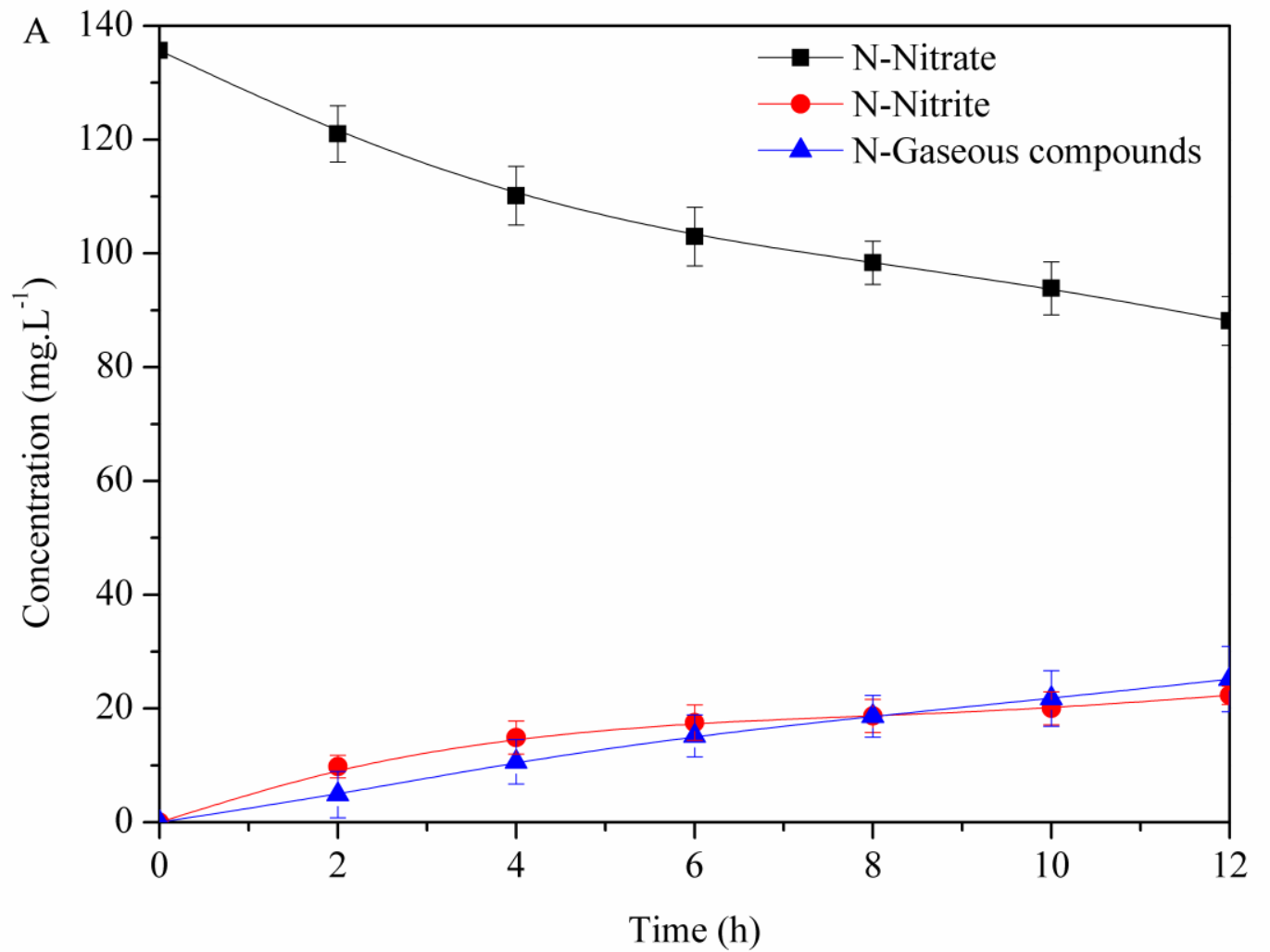

Time (h) 


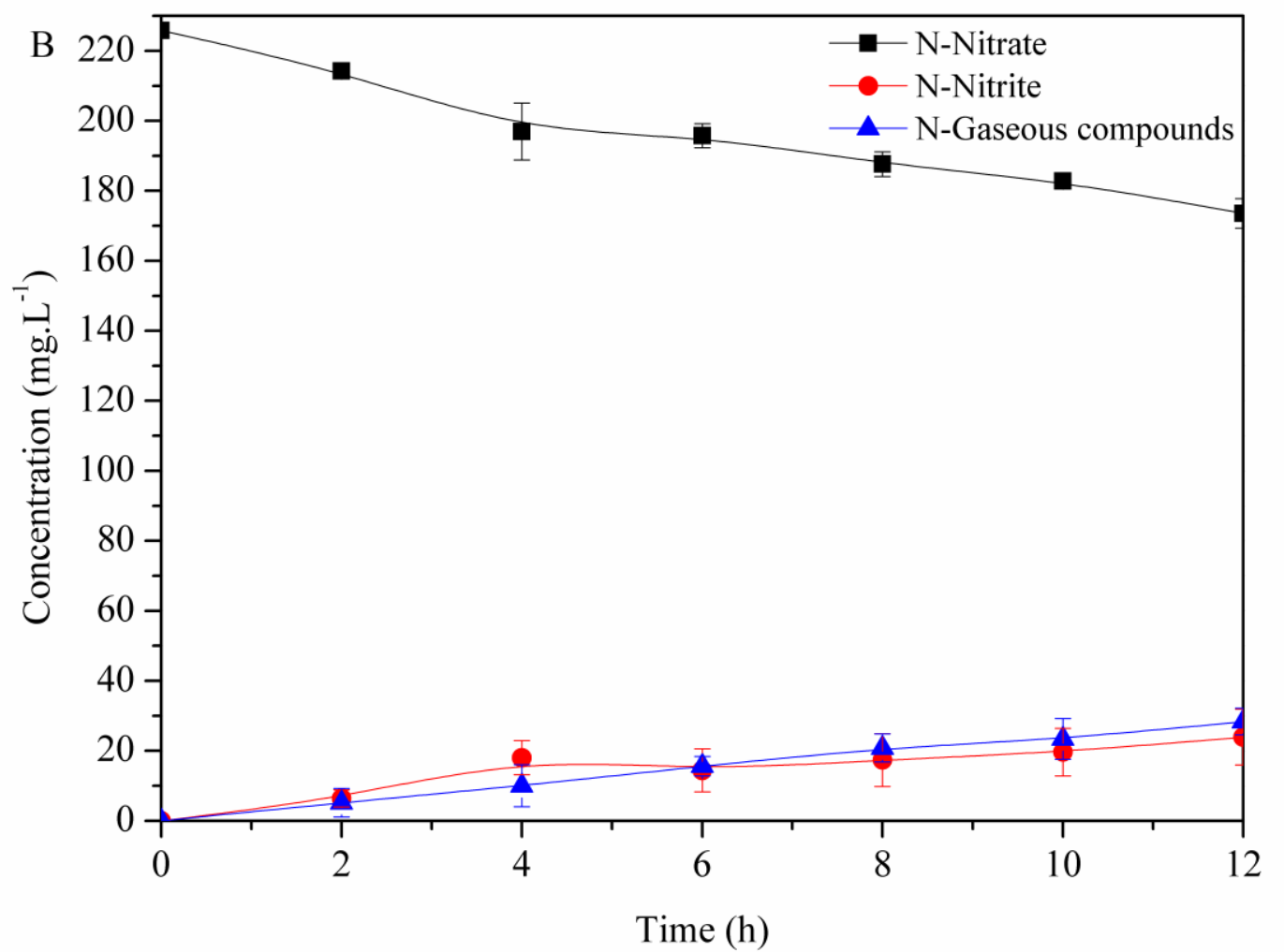




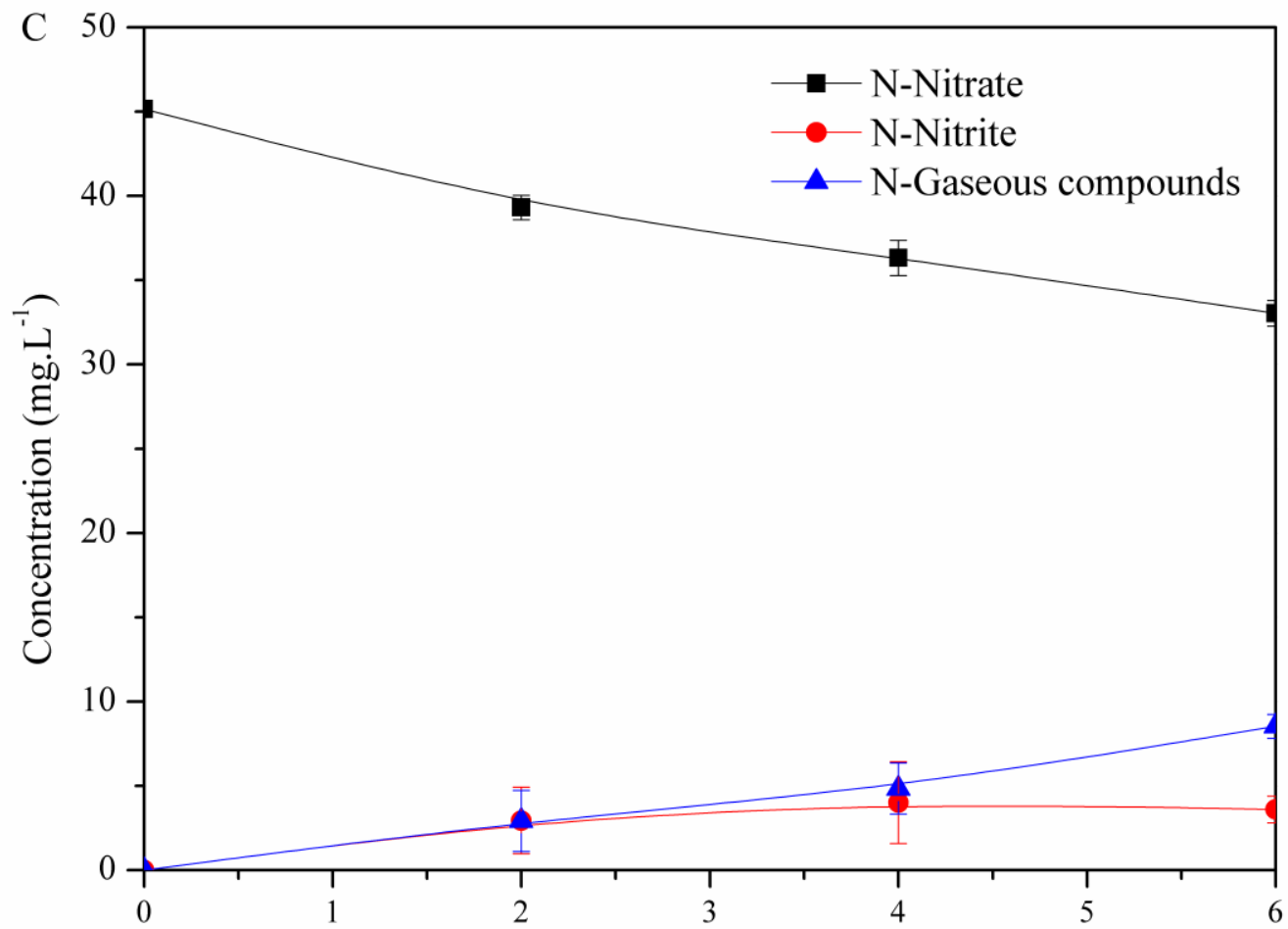

Time (h) 


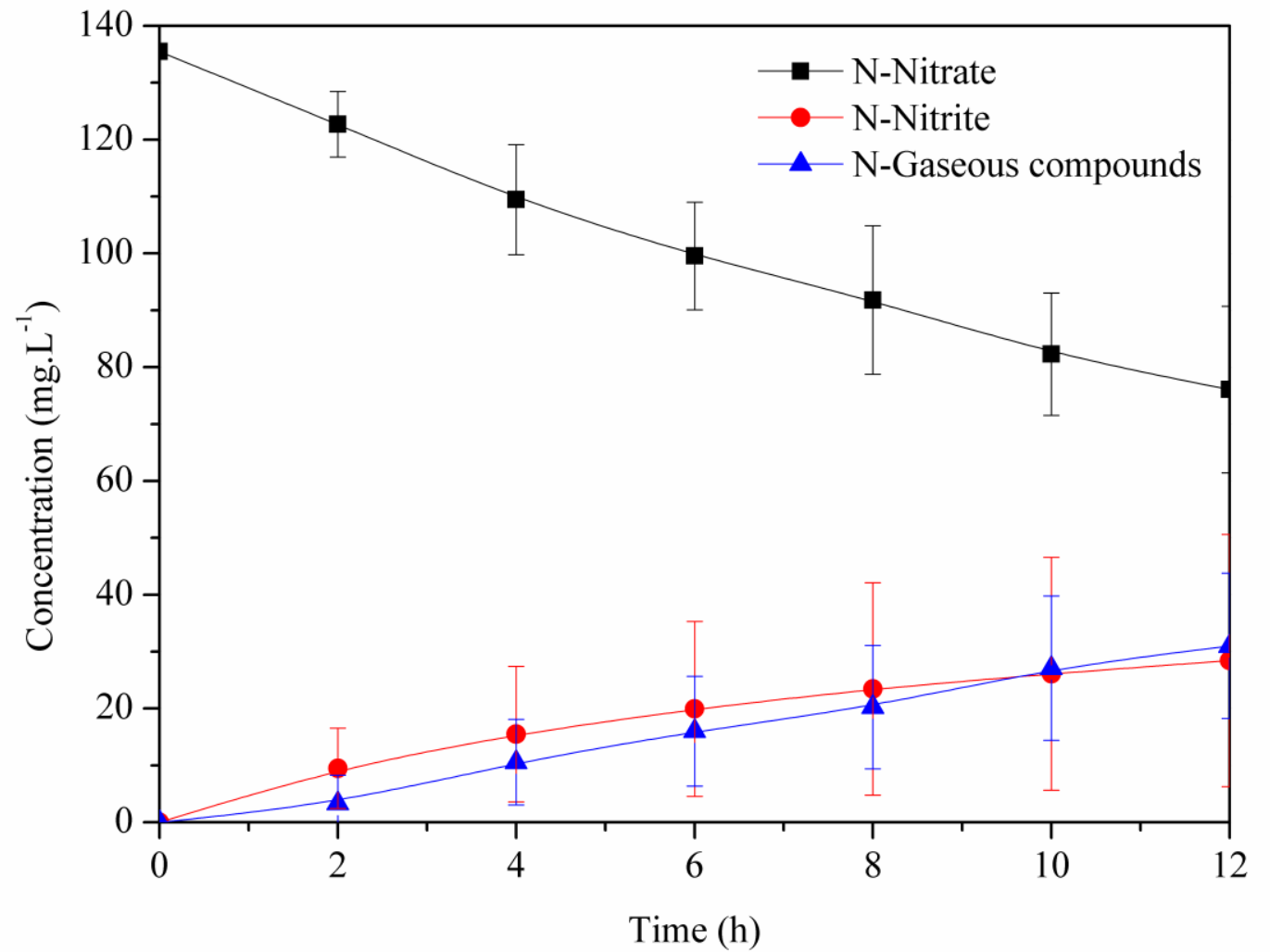

Time (h) 


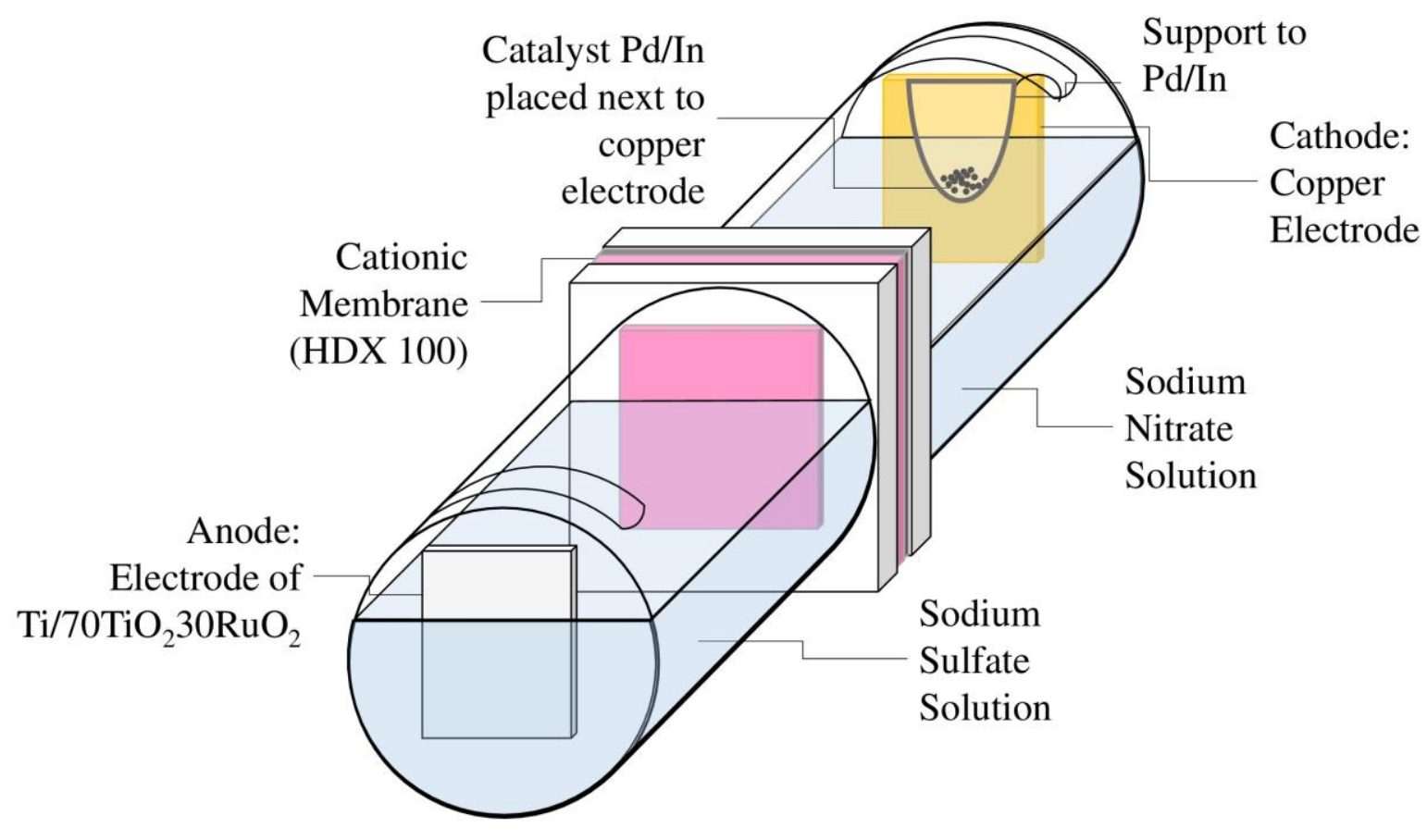



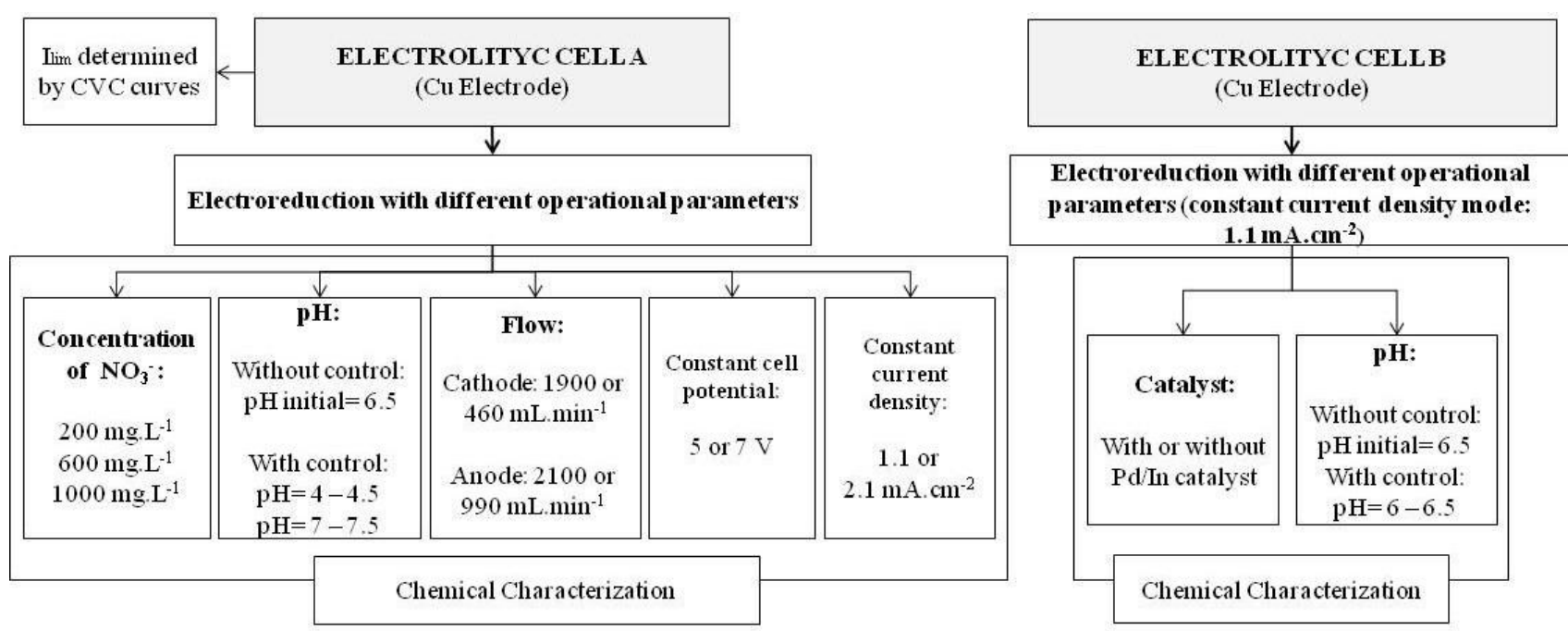
Electroreduction with different op erational parameters (constant current density mode:

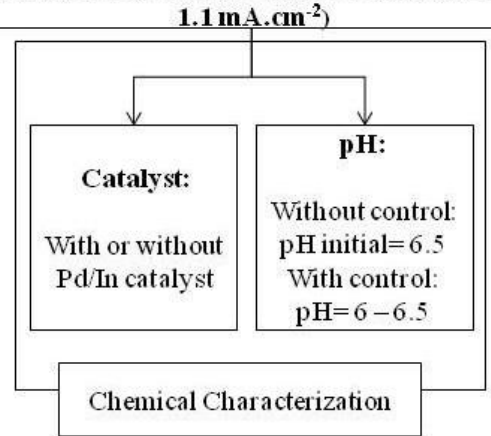


Cationic Membrane

(HDX 100)

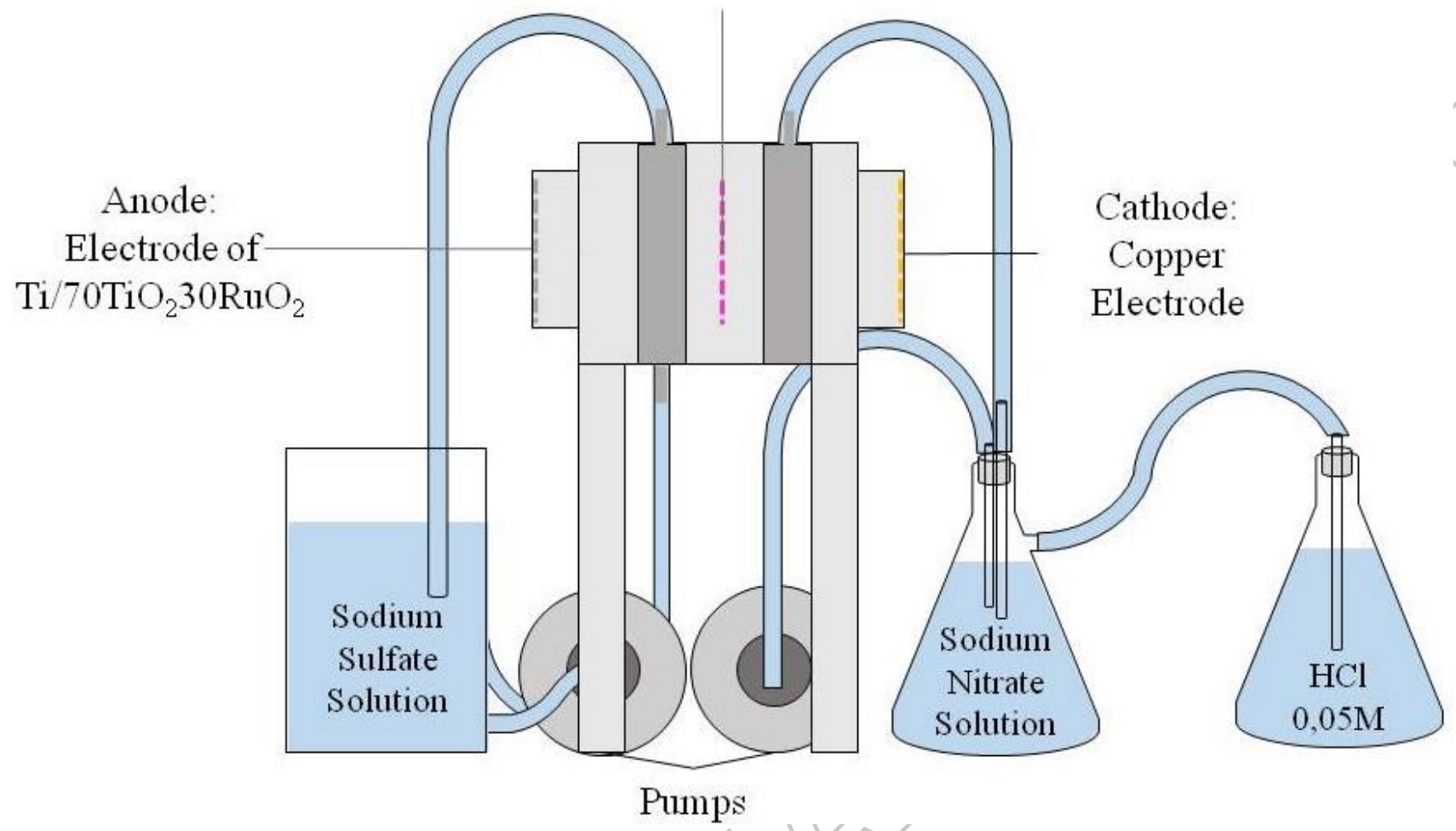




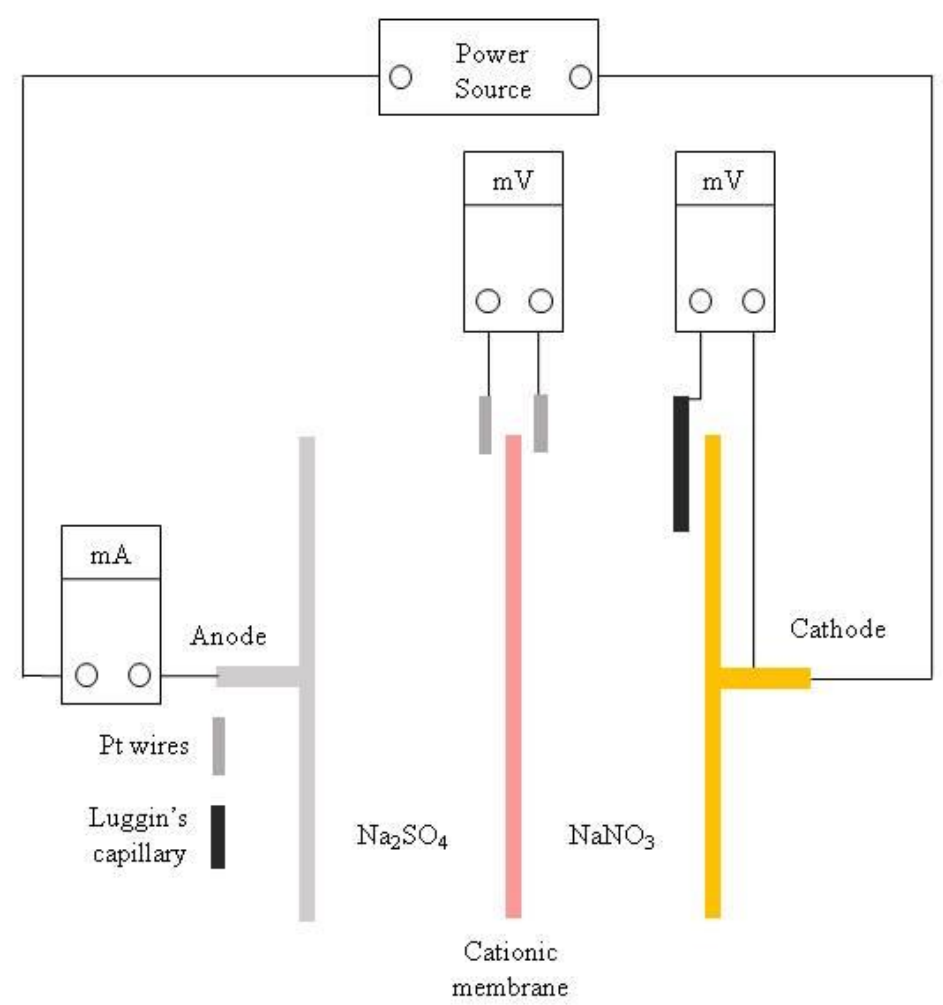

